\title{
Beyond the energy balance: exergy analysis of an industrial roller kiln firing porcelain tiles
}

\author{
S. Ferrer ${ }^{1}$; A. Mezquita ${ }^{1}$; V.M. Aguilella ${ }^{2}$; E. Monfort ${ }^{1}$ \\ ${ }^{1}$ Instituto de Tecnología Cerámica. Asociación de Investigación de las Industrias Cerámicas, \\ Universitat Jaume I. Castellón. ²Departamento de Física, Universitat Jaume I, Castellón, Spain
}

Corresponding author: S. Ferrer

e-mail: salvador.ferrer@itc.uji.es

Phone: 34964342424 / Fax: 34964342425

Address: ITC Campus Riu Sec 12006 Castellón. Spain

\begin{abstract}
The ceramic tile manufacturing process consumes large amounts of energy, mainly in the firing stage. Firing usually takes place in natural gas-fuelled continuous roller kilns, the most widely used tile firing facilities worldwide, which typically exhibit low energy efficiency (generally 5 to $20 \%$ ). This paper investigates the application of energy and exergy balances to an industrial roller kiln firing porcelain tiles in order to identify the most critical parameters affecting kiln energy efficiency and propose ways of improving kiln energy performance. The experimental kiln measurements and thermodynamic calculations confirmed the kiln's low energy performance $(15 \%)$. Exergy analysis showed that $83 \%$ of the total exergy input into the kiln was destroyed, only $10 \%$ of the exergy input being kept in the physico-chemical transformations of the ceramic tile composition. The main sources of irreversibilities: natural gas combustion, heat transfer in the fired tile cooling process, and heat transfer through the kiln surfaces, were identified and quantified. The study shows that waste heat (over 61\%) recovery could be expected to significantly increase kiln energy performance. Finally, further measures are proposed for optimising kiln energy efficiency.
\end{abstract}

Keywords: energy balance, exergy analysis, efficiency, irreversibility, ceramic roller kiln, firing. 


\section{Introduction}

World ceramic tile production was about 13500 million square metres in 2017, the main tile production areas being in Europe and in Asia, which accounted for about 2000 and 9400 million square metres, respectively [1]. The top five ceramic tile producers were China, India, Brazil, Vietnam, and Spain. In the European Union, Spain and Italy were the biggest ceramic tile producers, accounting for about $70 \%$ of EU production.

The natural gas-fuelled roller hearth kiln technology studied in this paper is similar to the most widely used ceramic tile firing technique in the world. In 2017, an estimated 8000 roller kilns were manufacturing ceramic tiles globally [2]. The study can therefore readily be extrapolated to such facilities worldwide.

Considering standard average energy consumption per kiln in 2011 [2][3], annual world energy consumption in ceramic tile firing, mainly by natural gas combustion, may be estimated at $1.82 \cdot 10^{5} \mathrm{GWh}\left(14 \mathrm{kWh} / \mathrm{m}^{2}\right.$ relative to the Lower Heating Value (LHV) [3]). Figure 1 schematically illustrates the main stages of the glazed ceramic tile manufacturing process: raw materials preparation (by dry milling and wetting or wet milling and spray drying), forming by pressing, drying, glazing and decorating, and firing [4][5].

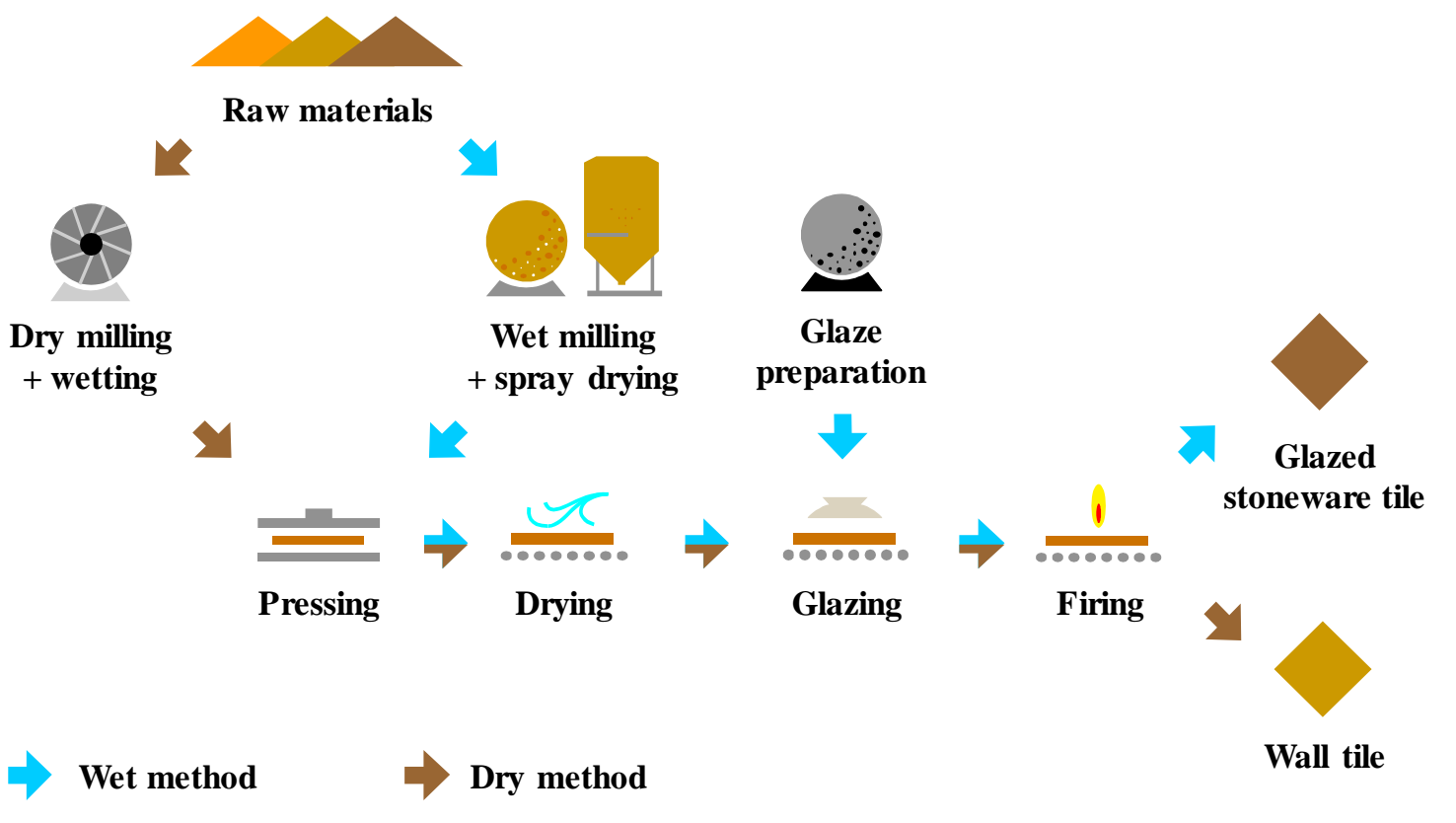

Figure 1. Schematic illustration of the glazed tile manufacturing process. 
In wet milling, currently the most common raw materials preparation method [6], thermal energy consumption takes place mainly in three process stages: spray drying (in which the milled ceramic slurry needs to be dried for semi-dry pressing); drying (after the green tile body has been formed); and firing. In tile manufacture by wet milling, firing accounts for more than $50 \%$ of overall thermal energy consumption [7][8][9]. In traditional ceramic tile manufacture, from an energy viewpoint, the firing stage is the most important process stage. Firing supplies the heat needed for the required physico-chemical transformations in the tile composition to develop. These

55 transformations provide the product with the desired technical and aesthetic properties. The thermal energy needed to fire ceramic tiles usually stems from natural gas combustion, a process that produces $\mathrm{CO}_{2}$ emissions.

In Europe, ceramic tile manufacturing companies with a production capacity of more than 75 tonnes per day must comply with EU legislation on greenhouse gas emissions (see Annex I of 60 [10] and [11]). Consequently, as $\mathrm{CO}_{2}$ emissions in the tile industry are mainly conditioned by fossil fuel combustion processes, given the emission allocation method, which is based on the socalled benchmarking system, companies with higher energy efficiencies will have greater competitive advantages [7][8].

A review of energy and exergy studies on the ceramic tile firing process revealed lacunae in knowledge in regard to kiln energy performance. A literature survey ([8, 15-18]) on energy analyses of industrial kilns firing ceramic materials showed that studies focused mainly on energy saving. However, analyses based on the first law of thermodynamics quantify all energy inputs and outputs identically, without considering energy quality or its degradation during transformations. These limitations in energy analysis have led exergy analysis, which provides a better understanding of such systems and processes, to emerge as a powerful tool in engineering evaluations.

Exergy analysis is a particularly suitable approach for more efficient use of resources, since it enables the location, types, and true magnitudes of waste and loss to be identified [19]. The main objective of kiln exergy analysis is to provide a clear image of the process, identify and quantify 
75 irreversibilities and sources of energy inefficiency and exergy destruction, distinguish the quality of energy consumption, select optimum firing conditions, and reduce the ceramic kiln's environmental impact. Energy and exergy analysis advantages have been extensively discussed in studies of other industries, such as the lime [20-22], plaster [23-25], iron [26-29], steel [30], silicon [31], nickel [32], and especially the cement industry [33-42], as well as of power plants [43-45]. Although numerous studies have evaluated thermal efficiency and sought to optimise ceramic tile firing kilns $[2][3][8][9][15][17][18][46-51]$, mainly addressing technical, environmental, or energy issues, few studies have focused on an exergy analysis of ceramic processing [52-56]. Nor is there is a clear methodology for the analysis and interpretation of results. No studies were found in the literature on the exergy analysis of natural gas-fuelled roller kilns, currently the most widely used kiln for manufacturing ceramic tiles worldwide.

In this study, a comprehensive energy analysis methodology has been adapted to an industrial roller kiln firing porcelain tiles. The heat losses through the kiln surfaces were experimentally quantified using a thermographic camera instead of being estimated by the difference between input and output energy, the most commonly used methodology. The thermographic camera allowed heat losses to be analysed in detail, this being of the utmost importance in processes where this output is very significant.

In the literature survey performed on the energy analysis of industrial processes, which was not only limited to ceramic processes, it was observed that the only chemical reactions included were fuel combustion reactions, while very few studies included an estimation of the chemical exergy involved in the materials processing reactions. In this study, the energy needed for the required physico-chemical transformations to develop in the ceramic tile composition during firing, which was the only strictly unrecoverable energy, was therefore also considered. The paper thus goes beyond the conventional energy balance by including a detailed exergy analysis and puts forward some suggestions to increase kiln energy performance. 


\begin{tabular}{|c|c|c|c|}
\hline Nomenclature & & & \\
\hline $\mathbf{A}$ & Area $\left(\mathrm{m}^{2}\right)$ & & Greek Symbols \\
\hline$\dot{\mathbf{A}}$ & Exergy rate $(\mathrm{kW})$ & $\rho$ & Density $\left(\mathrm{kg} / \mathrm{m}_{\mathrm{N}}^{3}\right)$ \\
\hline$\dot{A}_{D}$ & Exergy destruction rate $(\mathrm{kW})$ & $\eta$ & Energy performance $(\%)$ \\
\hline$\overline{\mathbf{a}}_{\text {chi }}$ & Molar chemical exergy of stream i $(\mathrm{kJ} / \mathrm{kmol})$ & $\eta$ & Efficiency $(\%)$ \\
\hline$\overline{\mathbf{a}}_{\mathbf{c h}, \mathbf{j}}$ & $\begin{array}{l}\text { Molar chemical standard exergy of component } \\
\qquad \mathrm{j}(\mathrm{kJ} / \mathrm{kmol})\end{array}$ & $\boldsymbol{\sigma}$ & $\begin{array}{l}\text { Stefan-Boltzmann constant } \\
\left(\mathrm{J} /\left(\mathrm{m}^{2} \mathrm{sK}^{4}\right)\right)\end{array}$ \\
\hline $\mathbf{h}_{\mathbf{c}}$ & $\begin{array}{l}\text { Coefficient of heat transmission by convection } \\
\qquad\left(\mathrm{J} /\left(\mathrm{m}^{2} \mathrm{sK}^{1,25}\right)\right)\end{array}$ & $\varepsilon$ & Emissivity \\
\hline $\mathbf{c}_{\mathbf{p}}$ & Specific heat $(\mathrm{kJ} / \mathrm{kg} \mathrm{K})$ & & Subscript \\
\hline$\overline{\mathbf{c}}_{\mathbf{p j}}$ & Molar heat of component $\mathrm{j}(\mathrm{kJ} / \mathrm{kmol} \mathrm{K})$ & $\mathbf{0}$ & Reference environment \\
\hline $\mathbf{g}_{\mathbf{j}}$ & Specific Gibbs energy of component j (kJ/kg) & c & Natural gas for combustion \\
\hline $\mathbf{h}_{\mathbf{j}}$ & Specific enthalpy of component $\mathrm{j}(\mathrm{kJ} / \mathrm{kg})$ & ca & Cooling air \\
\hline$\overline{\mathbf{h}}_{\mathbf{j}}$ & Molar enthalpy of component $\mathrm{j}(\mathrm{kJ} / \mathrm{kmol})$ & cg & Cooling air exhaust gases \\
\hline$\dot{\mathbf{H}}$ & Enthalpy rate $(\mathrm{kW})$ & ch & Chemical \\
\hline $\mathbf{h}_{\mathrm{gH}}$ & $\begin{array}{c}\text { Enthalpy of combustion of natural gas relative } \\
\text { to HHV }(\mathrm{kWh} / \mathrm{kg})\end{array}$ & d & Dilution air \\
\hline$h_{g L}$ & $\begin{array}{l}\text { Enthalpy of combustion of natural gas relative } \\
\text { to LHV }(\mathrm{kWh} / \mathrm{kg})\end{array}$ & $\mathbf{f}$ & Fired tiles \\
\hline$\dot{\mathbf{m}}$ & Mass flow rate $(\mathrm{kg} / \mathrm{s})$ & fg & Flue gases \\
\hline $\mathbf{M}_{\mathbf{i}}$ & Molecular weight of stream i $(\mathrm{kg} / \mathrm{kmol})$ & g & Natural gas \\
\hline $\mathbf{m}_{\mathrm{N}}^{3}$ & Normal cubic metre & $\mathbf{i}$ & Process stream i \\
\hline $\mathbf{P}$ & Pressure $(\mathrm{kPa})$ & in & Input \\
\hline$\dot{\mathbf{Q}}$ & Heat transfer rate $(\mathrm{kW})$ & $\mathbf{j}$ & Component $\mathrm{j}$ of process stream $\mathrm{i}$ \\
\hline$\overline{\mathbf{R}}$ & $\begin{array}{l}\text { Universal constant of ideal gases (8.3143 } \\
\mathrm{kJ} / \mathrm{kmol} \mathrm{K})\end{array}$ & out & Output \\
\hline $\mathbf{s}_{\mathbf{j}}$ & Specific entropy of component $\mathrm{j}(\mathrm{kJ} / \mathrm{kg} \mathrm{K})$ & $\mathbf{o x}$ & Oxidising air \\
\hline$\dot{\mathbf{S}}$ & Entropy rate $(\mathrm{kW} / \mathrm{K})$ & ph & Physical \\
\hline $\mathbf{T}$ & Temperature (K) & $\mathbf{r}$ & Reactions \\
\hline $\mathbf{w}_{\mathbf{j}}$ & $\begin{array}{l}\text { Mass fraction of component } j \text { ( } \mathrm{kg} \text { of } \\
\text { component } \mathrm{j} / \mathrm{kg} \text { total) }\end{array}$ & $\mathbf{u}$ & Unfired tiles \\
\hline \multirow[t]{2}{*}{$\mathbf{y}_{\mathbf{j}}$} & $\begin{array}{l}\text { Mole fraction of component } \mathrm{j}(\mathrm{kmol} \text { of } \\
\text { component } \mathrm{j} / \mathrm{kmol} \text { total) }\end{array}$ & ul & Uncontrolled losses \\
\hline & Abbreviations & $\mathbf{w}$ & Kiln walls and vault \\
\hline HHV & Higher Heating Value (kWh/kg) & & Superscript \\
\hline LHV & Lower Heating Value $(\mathrm{kWh} / \mathrm{kg})$ & $\mathbf{0}$ & Reference environment \\
\hline LOD & Limit of Detection & & \\
\hline
\end{tabular}




\section{Description of the facility}

The studied ceramic tile kiln was a single-deck roller kiln, 112.71 metres long, made up of 51 modules, each of which was 2.21 metres long, located inside a tile factory hall. The plane formed

105 by the rollers conveying the tiles divided the kiln into a top and a bottom chamber with different firing temperature settings. The product manufactured in the study was porcelain tile and the kiln worked in steady conditions during the experimental measurements. Heating was by natural gas combustion at the kiln burners, where air and gas were fed in through different inlets. The studied kiln contained 168 burners. The oxidising agent at the burners was external air fed in at hall ambient temperature. The flue gases produced by natural gas combustion at the burners were exhausted into the atmosphere outside the factory hall through a single flue gas stack at the kiln entrance. The flue gas stack contained an external ambient air intake (dilution air) to reduce flue gas temperature and protect the exhaust fan. The firing zone was separated from the cooling zone by a firewall. The fired ceramic tiles were cooled down to practically external ambient temperature in three stages after firing as they travelled through the kiln. In the first and last stages, external ambient air was directly injected into the kiln to cool the fired tiles while, between 600 and $500{ }^{\circ} \mathrm{C}$, a much gentler intermediate cooling stage was needed because the allotropic transformation of quartz takes place at about $573{ }^{\circ} \mathrm{C}$. The hot gases from the cooling stages were released into the atmosphere outside the factory hall through the cooling exhaust gas stack. The studied kiln is schematically illustrated in figure 2 .

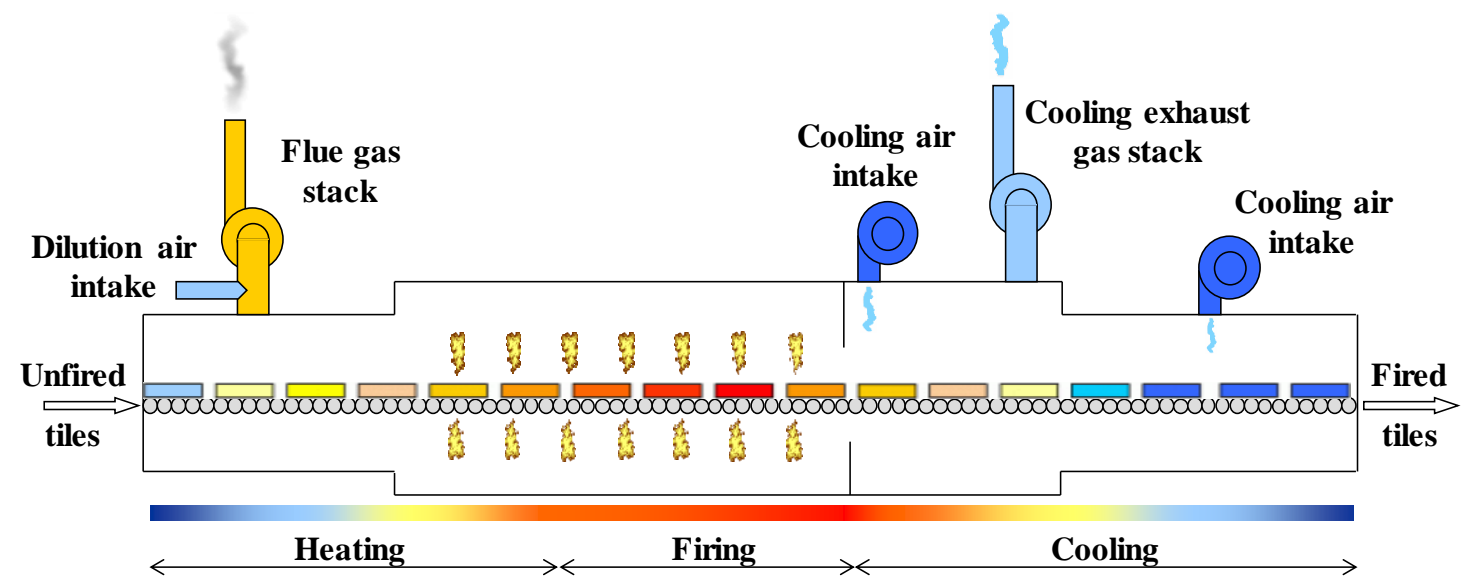

Figure 2. Streams involved in the studied porcelain tile kiln. 


\section{Materials and methods}

125

This section describes the characteristics of the materials and the characterisation methodologies used in the studied firing process. For the sake of simplicity, the reader is referred to previous publications [57] for a full description of the materials characterisation. The present paper focuses on the specific methodology introduced in this study.

\subsection{Materials characteristics}

i) Fuel: natural gas

Table 1 details the chemical composition and main properties of the natural gas fuel used in the studied kiln, which correspond to those of the average natural gas fuel supplied to the ceramic tile industry in the Castellón district [58].

Table 1. Average values of the main characteristics of the natural gas fuel used.

\begin{tabular}{|c|c|c|c||c|c|c|}
\hline \multicolumn{2}{|c|}{ Parameter } & Symbol & Value & Property & Symbol & Value \\
\hline \multirow{4}{*}{$\begin{array}{c}\text { Chemical } \\
\text { composition } \\
(\% \text { by volume })\end{array}$} & Methane & $\mathrm{CH}_{4}(\mathrm{~g})$ & 90 & Density at $25^{\circ} \mathrm{C}\left(\mathrm{kg} / \mathrm{m}_{\mathrm{N}}^{3}\right)$ & $\rho_{\mathrm{g}}$ & 0.726 \\
\cline { 2 - 7 } & Ethane & $\mathrm{C}_{2} \mathrm{H}_{6}(\mathrm{~g})$ & 7.5 & Molecular weight $(\mathrm{kg} / \mathrm{kmol})$ & $\mathrm{M}_{\mathrm{g}}$ & 17.76 \\
\cline { 2 - 7 } & Propane & $\mathrm{C}_{3} \mathrm{H}_{8}(\mathrm{~g})$ & 1.5 & $\begin{array}{c}\text { Higher Heating Value }(\mathrm{HHV}) \\
(\mathrm{kWh} / \mathrm{kg})\end{array}$ & $\mathrm{h}_{\mathrm{gH}}$ & 15.07 \\
& Butane & $\mathrm{C}_{4} \mathrm{H}_{10}(\mathrm{~g})$ & 0.40 & $\begin{array}{c}\text { Lower Heating Value }(\mathrm{LHV}) \\
(\mathrm{kWh} / \mathrm{kg})\end{array}$ & $\mathrm{h}_{\mathrm{gL}}$ & 13.62 \\
\cline { 2 - 7 } & Nitrogen & $\mathrm{N}_{2}(\mathrm{~g})$ & 0.60 & Specific heat $(\mathrm{kJ} / \mathrm{kgK})$ & $\mathrm{c}_{\mathrm{pg}}$ & 2.152 \\
\hline
\end{tabular}

The $\mathrm{CO}_{2}$ emission factor considered for natural gas was $56.3 \mathrm{t} \mathrm{CO} / \mathrm{TJ}[59]$.

\section{ii) Flue and cooling exhaust gas stream characteristics}

140 The chemical composition of the kiln flue gases was experimentally determined (table 2) using a portable combustion analyser system (Kane $350 \mathrm{XL}$ ). The exhausted kiln cooling gases (table 2) were basically made up of air, and their composition was determined using the same gas analyser.

Table 2. Flue and cooling exhaust gas composition and temperature.

\begin{tabular}{|c|c|c|c|}
\hline \multicolumn{2}{|c|}{ Parameters } & Flue gases & Cooling exhaust gases \\
\hline \multirow{3}{*}{$\begin{array}{c}\text { Chemical composition } \\
\text { (\% by volume) }\end{array}$} & $\mathrm{CO}_{2}$ & 3.26 & --- \\
\cline { 2 - 4 } & $\mathrm{H}_{2} \mathrm{O}$ & 6.19 & --- \\
\cline { 2 - 4 } & $\mathrm{O}_{2}$ & 13.98 & 21.00 \\
\cline { 2 - 4 } & $\mathrm{N}_{2}$ & 76.56 & 79.00 \\
\hline \multicolumn{2}{|c|}{ Temperature (K) } & 511.8 & 425.0 \\
\hline
\end{tabular}




\section{iii) Studied unfired and fired porcelain tile composition}

145 Porcelain tile chemical composition was determined by wavelength dispersive X-ray fluorescence spectrometry (WD-XRF), using a PANALYTICAL Axios WD-XRF spectrometer with Rh tube and $4 \mathrm{~kW}$ power. Reference materials were used to guarantee measurement traceability. The chemical analysis of the unfired porcelain tile composition is shown in table 3.

Table 3. Chemical analysis and loss on ignition (LOI) of the unfired porcelain tile composition (\% by weight).

\begin{tabular}{|c|c|}
\hline Oxides & $\begin{array}{c}\text { Unfired porcelain tile } \\
\text { composition (\% by weight) }\end{array}$ \\
\hline $\mathrm{SiO}_{2}$ & 73.84 \\
\hline $\mathrm{Al}_{2} \mathrm{O}_{3}$ & 19.59 \\
\hline $\mathrm{Fe}_{2} \mathrm{O}_{3}$ & $<0.50$ \\
\hline $\mathrm{CaO}$ & 0.40 \\
\hline $\mathrm{K}_{2} \mathrm{O}$ & 0.97 \\
\hline $\mathrm{Na}_{2} \mathrm{O}$ & 5.20 \\
\hline $\mathrm{LOI}$ & 3.74 \\
\hline $\mathrm{Total}$ & 100 \\
\hline
\end{tabular}

The mineralogical phases of the material streams were determined by XRD analysis. The results obtained for the unfired and fired porcelain tile compositions are shown in table 4 .

Table 4. Mineralogical analysis of the unfired and fired porcelain tile compositions ( $\%$ by weight).

\begin{tabular}{|c|c|c|}
\hline Mineralogical phases & $\begin{array}{c}\text { Unfired tile } \\
\text { (\% by weight) }\end{array}$ & $\begin{array}{c}\text { Fired tile } \\
\text { (\% by weight })\end{array}$ \\
\hline Kaolinite & $19 \pm 2$ & $<\mathrm{LOD}$ \\
\hline Illite/Muscovite mica & $8 \pm 2$ & $<\mathrm{LOD}$ \\
\hline Potassium feldspar & $6 \pm 1$ & $<\mathrm{LOD}$ \\
\hline Albite & $36 \pm 1$ & $6 \pm 0.5$ \\
\hline Quartz & $31 \pm 3$ & $24 \pm 3$ \\
\hline Mullite & $<\mathrm{LOD}$ & $8 \pm 1$ \\
\hline Amorphous phase & $<\mathrm{LOD}$ & $62 \pm 4$ \\
\hline Total & 100 & 100 \\
\hline
\end{tabular}

Exergy calculations require knowing the change in enthalpy, entropy, and Gibbs energy of the

155 physico-chemical transformations occurring during ceramic tile firing. Taking into account the mineralogical phases in the unfired and fired tile compositions (table 4) and applying the analytical method proposed elsewhere [57] enabled the physico-chemical transformations most 
likely to occur to be identified. These are listed in table 5. Their standard enthalpies were taken from [57], whereas their entropy and Gibbs energy values were estimated from thermodynamic databases [60][61][62].

Table 5. Reactions considered during thermal treatment of the studied porcelain tile composition.

\begin{tabular}{|c|c|c|c|c|}
\hline Components & Reactions & $\begin{array}{c}\Delta \mathbf{h}_{\mathbf{j}} \\
(\mathbf{k J} / \mathbf{k g})\end{array}$ & $\begin{array}{c}\Delta \mathbf{s}_{\mathbf{j}} \\
(\mathbf{k J} / \mathbf{k g K})\end{array}$ & $\begin{array}{c}\Delta \mathbf{g}_{\mathbf{j}} \\
(\mathbf{k J} / \mathbf{k g})\end{array}$ \\
\hline Free water & $\mathrm{H}_{2} \mathrm{O}(\mathrm{l}) \rightarrow \mathrm{H}_{2} \mathrm{O}(\mathrm{g})$ & 2500 & 6.60 & 476 \\
\hline \multicolumn{5}{|c|}{ Clay mineral dehydroxylation } \\
\hline Kaolinite & $\begin{array}{c}\mathrm{Al}_{2} \mathrm{O}_{3} \cdot 2 \mathrm{SiO}_{2} \cdot 2 \mathrm{H}_{2} \mathrm{O}(\mathrm{s}) \rightarrow \mathrm{Al}_{2} \mathrm{O}_{3} 2 \mathrm{SiO}_{2}(\mathrm{~s})+ \\
2 \mathrm{H}_{2} \mathrm{O}(\mathrm{g})\end{array}$ & 1158 & 1.34 & $846^{1}$ \\
\hline $\begin{array}{l}\text { Illite/Muscovite } \\
\text { mica }\end{array}$ & $\begin{array}{c}(1 / 2) \mathrm{K}_{2} \mathrm{O} .(3 / 2) \mathrm{Al}_{2} \mathrm{O}_{3} .3 \mathrm{SiO}_{2} \mathrm{H}_{2} \mathrm{O}(\mathrm{s}) \rightarrow \\
(1 / 2) \mathrm{K}_{2} \mathrm{O} .(1 / 2) \mathrm{Al}_{2} \mathrm{O}_{3} .3 \mathrm{SiO}_{2}(\mathrm{~s})+\mathrm{Al}_{2} \mathrm{O}_{3}(\mathrm{~s})+ \\
\mathrm{H}_{2} \mathrm{O}(\mathrm{g})\end{array}$ & 374 & 0.33 & 673 \\
\hline \multicolumn{5}{|c|}{ Quartz inversion } \\
\hline Quartz inversion & $\alpha-\mathrm{SiO}_{2}(\mathrm{~s}) \rightarrow \beta-\mathrm{SiO}_{2}(\mathrm{~s})$ & 11.7 & 0.01 & 7.18 \\
\hline \multicolumn{5}{|c|}{ Crystallisation of calcium phases - Formation of new crystalline phases } \\
\hline Mullite & $\begin{array}{c}\mathrm{Al}_{2} \mathrm{O}_{3} \cdot 2 \mathrm{SiO}_{2}(\mathrm{~s}) \underset{(4 / 3) \mathrm{SiO}_{2}(\mathrm{~s})}{\rightarrow}(1 / 3) 3 \mathrm{Al}_{2} \mathrm{O}_{3} \cdot 2 \mathrm{SiO}_{2}(\mathrm{~s})+ \\
\text { ( }\end{array}$ & -280 & 0.02 & -642 \\
\hline \multicolumn{5}{|c|}{ Glassy phase formation by fusion of the crystalline phase } \\
\hline $\begin{array}{l}\text { Potassium } \\
\text { feldspar }\end{array}$ & $\mathrm{K}_{2} \mathrm{O} . \mathrm{Al}_{2} \mathrm{O}_{3} \cdot 6 \mathrm{SiO}_{2}(\mathrm{~s}) \rightarrow \mathrm{K}_{2} \mathrm{O} . \mathrm{Al}_{2} \mathrm{O}_{3} \cdot 6 \mathrm{SiO}_{2}(\mathrm{l})$ & 207 & 0.17 & 139 \\
\hline Albite & $\mathrm{Na}_{2} \mathrm{O} \cdot \mathrm{Al}_{2} \mathrm{O}_{3} \cdot 6 \mathrm{SiO}_{2}(\mathrm{~s}) \rightarrow \mathrm{Na}_{2} \mathrm{O} \cdot \mathrm{Al}_{2} \mathrm{O}_{3} \cdot 6 \mathrm{SiO}_{2}(\mathrm{l})$ & 226 & 0.17 & 177 \\
\hline
\end{tabular}

\section{iv) Porcelain tile characteristics and production parameters}

Table 6 shows the main characteristics of the manufactured porcelain tile and kiln working conditions during the experimental measurements.

Table 6. Main fired porcelain tile characteristics and kiln working conditions.

\begin{tabular}{|c|c|c|}
\hline \multirow{4}{*}{ Fired porcelain tile } & Value \\
\cline { 2 - 3 } & Surface size & $60 \mathrm{~cm} \mathrm{x} 60 \mathrm{~cm}$ \\
\cline { 2 - 3 } & Thickness & $11.31 \mathrm{~mm}$ \\
\hline \multirow{4}{*}{ Firing cycle } & Specific weight & $25.5 \mathrm{~kg} / \mathrm{m}^{2}$ fired tile \\
\cline { 2 - 3 } & Duration (cold to cold) & 50 minutes \\
\cline { 2 - 3 } & Peak temperature & $1463 \mathrm{~K}$ \\
\cline { 2 - 3 } & Kiln production & $7264 \mathrm{~m}^{2} /$ day \\
\cline { 2 - 3 } & & $7718 \mathrm{~kg} \mathrm{fired} \mathrm{tile} / \mathrm{h}$ \\
\cline { 2 - 3 } & Natural gas flow rate & $330 \mathrm{~kg} / \mathrm{h}$ \\
\hline
\end{tabular}




\subsection{Theoretical approach and balance procedure}

In this section, the mass, energy, and exergy balance of a continuous industrial ceramic tile roller kiln are discussed. The tile firing kiln is thermodynamically considered a control volume (open system). The following assumptions are typically made during data collection in industrial practice:

a) The system is assumed to operate in steady state.

b) Changes in kinetic and potential energy and work (for instance roller conveying) of input and output flows are deemed negligible. Electrical energy consumption was therefore not taken into account because this was thermodynamically insignificant compared to thermal energy consumption [9].

c) Air, natural gas, and exhaust flue gases are considered ideal gases.

d) In accordance with the IUPAC sign convention, energy input and output are assumed positive and negative, respectively.

180 Exergy calculations require defining a reference environment, which thus has a known temperature $\left(\mathrm{T}_{0}=298 \mathrm{~K}\right)$, pressure $\left(\mathrm{P}_{0}=101.325 \mathrm{kPa}\right)$, and chemical composition. Therefore, it should be borne in mind that the exergy values will always depend on the reference environment. In this study, the reference environment proposed by Szargut ([63][64]) was used, since it is a widely accepted criterion in the literature.

\subsection{Mass balance}

For an open system operating under steady-state conditions the basic mass balance equation is:

$$
\sum_{\mathrm{i}} \dot{\mathrm{m}}_{\mathrm{in}, \mathrm{i}}=\sum_{\mathrm{i}} \dot{\mathrm{m}}_{\mathrm{out}, \mathrm{i}}
$$

where $\dot{\mathrm{m}}_{\mathrm{in}, \mathrm{i}}$ and $\dot{\mathrm{m}}_{\mathrm{out}, \mathrm{i}}$ are the system's input and output mass flow rates, respectively. The mass balance of the studied tile firing kiln, see figure 3, comprised the input mass flows of natural gas $\left(\dot{\mathrm{m}}_{\mathrm{g}}\right)$, oxidising air $\left(\dot{\mathrm{m}}_{\mathrm{ox}}\right)$, cooling air $\left(\dot{\mathrm{m}}_{\mathrm{ca}}\right)$, dilution air $\left(\dot{\mathrm{m}}_{\mathrm{d}}\right)$, and unfired porcelain tiles $\left(\dot{\mathrm{m}}_{\mathrm{u}}\right)$, and the output mass flows of fired tiles $\left(\dot{\mathrm{m}}_{\mathrm{f}}\right)$, cooling exhaust gases $\left(\dot{\mathrm{m}}_{\mathrm{cg}}\right)$, and flue gases $\left(\dot{\mathrm{m}}_{\mathrm{fg}}\right)$ : 


$$
\dot{\mathrm{m}}_{\mathrm{g}}+\dot{\mathrm{m}}_{\mathrm{ox}}+\dot{\mathrm{m}}_{\mathrm{ca}}+\dot{\mathrm{m}}_{\mathrm{d}}+\dot{\mathrm{m}}_{\mathrm{u}}=\dot{\mathrm{m}}_{\mathrm{f}}+\dot{\mathrm{m}}_{\mathrm{cg}}+\dot{\mathrm{m}}_{\mathrm{fg}}
$$

\subsection{Energy balance}

Taking into account the assumptions detailed in Section 3.2, the basic energy balance is given by:

$$
\sum_{\mathrm{i}} \dot{\mathrm{H}}_{\mathrm{in}, \mathrm{i}}-\sum_{\mathrm{i}} \dot{\mathrm{H}}_{\mathrm{out}, \mathrm{i}}+\dot{\mathrm{Q}}=\sum \Delta \dot{\mathrm{H}}_{\mathrm{c}}+\sum \Delta \dot{\mathrm{H}}_{\mathrm{r}}
$$

where $\dot{H}_{i n, i}$ stands for the enthalpies of the system's input mass flow streams and $\dot{H}_{\text {out, }, i}$ stands for the enthalpies of the output mass flow streams. The term $\dot{Q}$ comprises the rate of heat transfer through the kiln walls and the uncontrolled heat losses. The term $\Delta \dot{\mathrm{H}}_{\mathrm{c}}$ comprises the enthalpy rate involved in the reactions that occurred during natural gas combustion (all of which were exothermic), and $\Delta \dot{\mathrm{H}}_{\mathrm{r}}$ corresponds to the overall enthalpy rate involved in the physico-chemical transformations that needed to develop in the material to yield the targeted product. The main input and output streams for typical continuous tile roller kilns and the context on which the energy balance was drawn up are illustrated in figure 3.

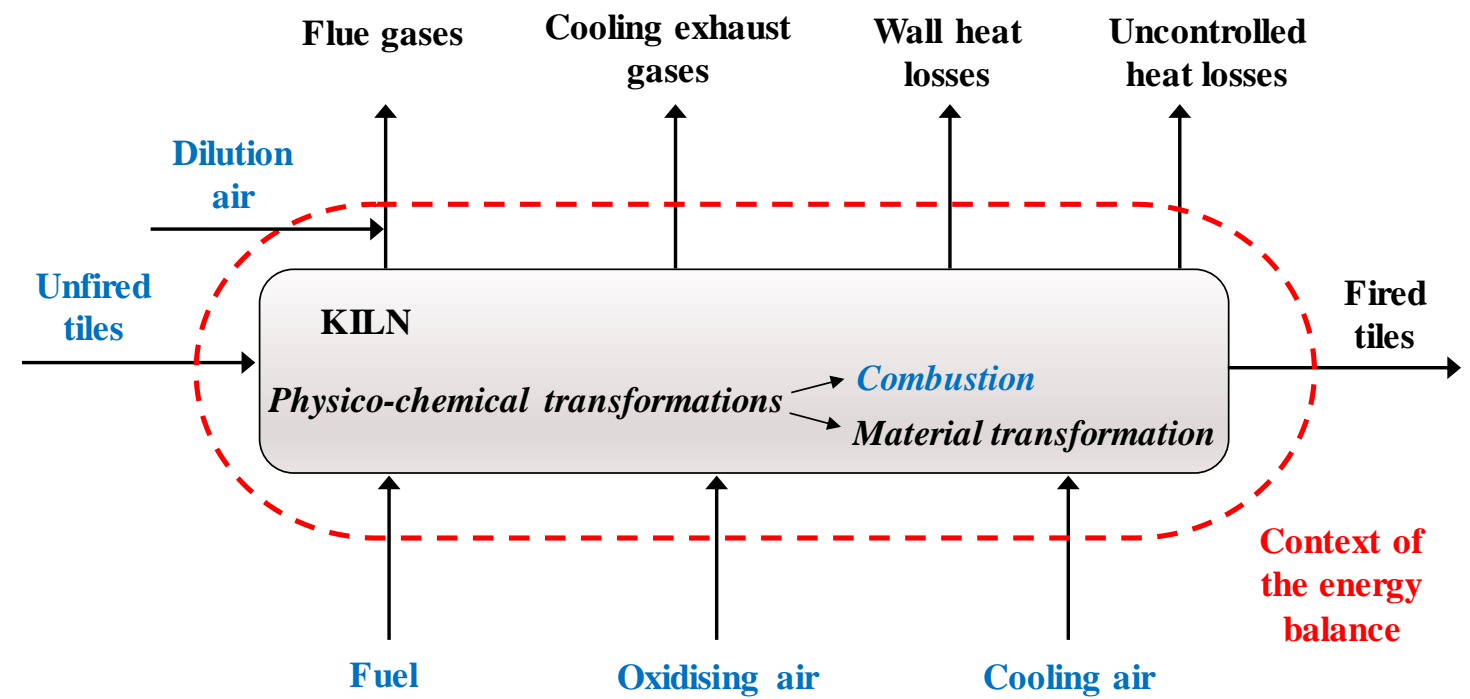

Figure 3. Streams involved in the mass and energy balance of a ceramic tile roller kiln.

Taking into account the mass and energy flows shown in figure 3, the term $\Sigma \dot{H}_{\text {in,i }}$ in equation (3) comprises the input flows of natural gas $\left(\dot{\mathrm{H}}_{\mathrm{g}}\right)$, oxidising air $\left(\dot{\mathrm{H}}_{\mathrm{ox}}\right)$, cooling air $\left(\dot{\mathrm{H}}_{\mathrm{ca}}\right)$, dilution air $\left(\dot{\mathrm{H}}_{\mathrm{d}}\right)$, and unfired porcelain tiles $\left(\dot{\mathrm{H}}_{\mathrm{u}}\right)$. The output flows $\left(\Sigma \dot{\mathrm{H}}_{\mathrm{out}, \mathrm{i}}\right)$ comprise the flue gases $\left(\dot{\mathrm{H}}_{\mathrm{fg}}\right)$, fired porcelain tiles $\left(\dot{\mathrm{H}}_{\mathrm{f}}\right)$, cooling exhaust gases $\left(\dot{\mathrm{H}}_{\mathrm{cg}}\right)$, heat losses through the kiln walls $\left(\dot{\mathrm{Q}}_{\mathrm{w}}\right)$, and 
uncontrolled heat losses $\left(\dot{\mathrm{Q}}_{\mathrm{ul}}\right)$. The reactions that occurred during the firing process involved enthalpy changes, where $\Delta \dot{\mathrm{H}}_{\mathrm{c}}$ corresponds to the exothermic reactions involved in natural gas combustion and $\Delta \dot{\mathrm{H}}_{\mathrm{r}}$ to the physico-chemical transformations that occurred in the ceramic tile composition. The following kiln energy balance was thus obtained:

$$
\dot{\mathrm{H}}_{\mathrm{g}}+\dot{\mathrm{H}}_{\mathrm{ox}}+\dot{\mathrm{H}}_{\mathrm{ca}}+\dot{\mathrm{H}}_{\mathrm{d}}+\dot{\mathrm{H}}_{\mathrm{u}}-\Delta \dot{\mathrm{H}}_{\mathrm{c}}=\dot{\mathrm{H}}_{\mathrm{fg}}+\dot{\mathrm{H}}_{\mathrm{f}}+\dot{\mathrm{H}}_{\mathrm{cg}}-\dot{\mathrm{Q}}_{\mathrm{w}}-\dot{\mathrm{Q}}_{\mathrm{ul}}+\Delta \dot{\mathrm{H}}_{\mathrm{r}}
$$

The enthalpies of the gaseous flows $\left(\dot{\mathrm{H}}_{\mathrm{ox}}, \dot{\mathrm{H}}_{\mathrm{ca}}, \dot{\mathrm{H}}_{\mathrm{d}}, \dot{\mathrm{H}}_{\mathrm{cg}}\right.$, and $\left.\dot{\mathrm{H}}_{\mathrm{fg}}\right)$ were obtained from thermodynamic tables [65] at their corresponding temperature. The enthalpy of natural gas flow $\left(\dot{\mathrm{H}}_{\mathrm{g}}\right)$ and the enthalpies for condensed phases $\left(\dot{\mathrm{H}}_{\mathrm{u}}\right.$ and $\left.\dot{\mathrm{H}}_{\mathrm{f}}\right)$ were calculated from their $\dot{\mathrm{H}}_{\mathrm{i}}^{0}$ values at

215 the reference environment temperature, $\mathrm{T}_{0}$, and from the tabulated specific heats, $\mathrm{c}_{\mathrm{pi}}$, as:

$$
\dot{\mathrm{H}}_{\mathrm{i}}=\dot{\mathrm{H}}_{\mathrm{i}}^{0}+\dot{\mathrm{m}}_{\mathrm{i}} \mathrm{c}_{\mathrm{pi}}\left(\mathrm{T}-\mathrm{T}_{0}\right)
$$

The heat losses through the kiln surfaces by convection and radiation were quantified according to $[66][67][68]:$

$$
\dot{\mathrm{Q}}_{\mathrm{w}}=\mathrm{h}_{\mathrm{c}} \cdot\left(\mathrm{T}_{\mathrm{w}}-\mathrm{T}_{0}\right)^{1.25} \cdot \mathrm{A}_{\mathrm{conv}}+\varepsilon \cdot \sigma \cdot\left[\left(\mathrm{T}_{\mathrm{w}}\right)^{4}-\left(\mathrm{T}_{0}\right)^{4}\right] \cdot \mathrm{A}_{\mathrm{rad}}
$$

where $h_{c}$ is the convection coefficient, $\varepsilon$ is surface emissivity, and $\sigma$ is the Stefan-Boltzmann constant. $\mathrm{A}_{\mathrm{conv}}$ and $\mathrm{A}_{\mathrm{rad}}$ are the surface areas available for convection and radiation, respectively, and $\mathrm{T}_{\mathrm{w}}$ is the wall surface temperature.

To quantify the energy losses through the kiln walls and vault $\left(\dot{Q}_{\mathrm{w}}\right)$, the kiln surfaces were divided into smaller areas and the average emissivity and surface temperature were determined in each, using an infrared camera (FLIR ThermaCAM ${ }^{\mathrm{TM}} \mathrm{E} 25$ ) with an accuracy of $\pm 2{ }^{\circ} \mathrm{C}$ and uncertainty 225 of $\mathrm{I}(\mathrm{k}=2)=1.4^{\circ} \mathrm{C}$. Figure 4 shows a thermographic image (a) and a photograph (b) of the kiln wall. 


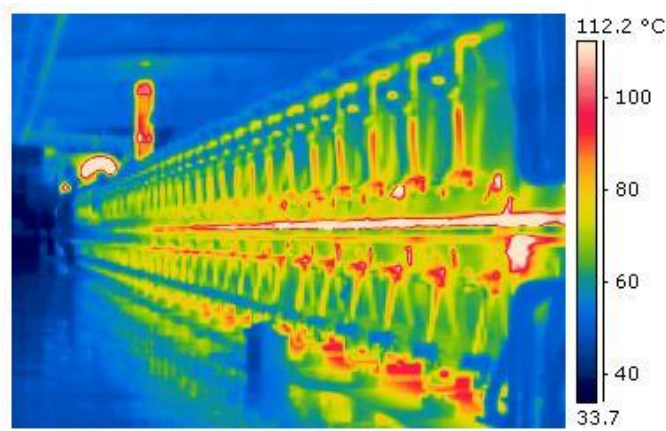

(a)

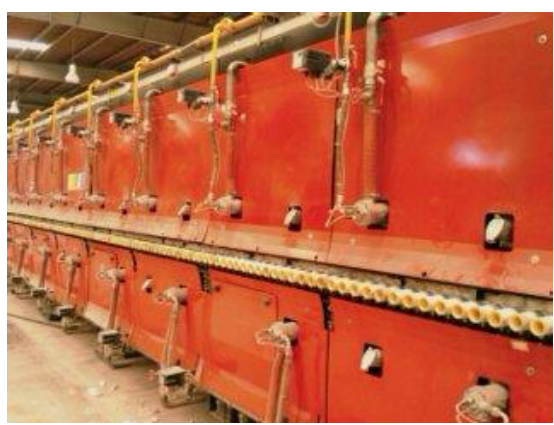

(b)

Figure 4. Thermographic image (a) and photo (b) of the right-hand wall of the kiln.

Figure 5 shows thermographic images taken at the kiln wall and vault of a kiln module clearly exhibiting a substantially higher average vault than wall temperature.

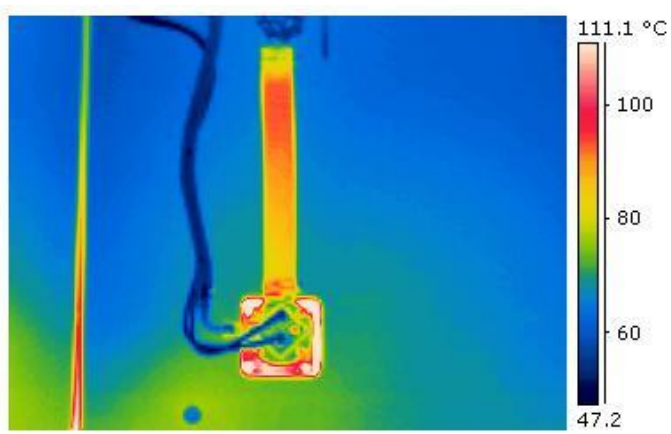

(a)

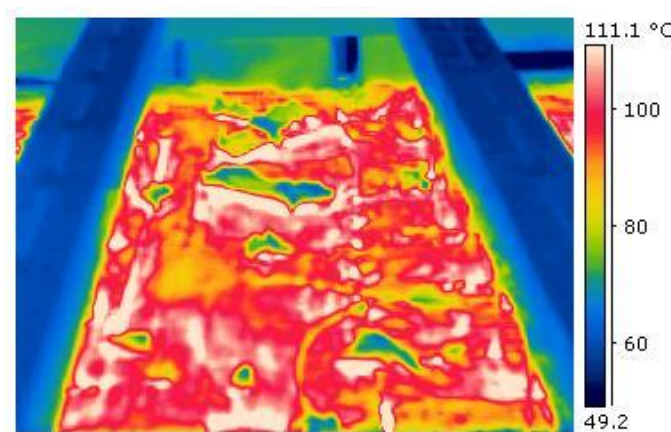

(b)

Figure 5. Thermographic image of the right-hand wall (a) and vault (b) of a kiln module.

235 Uncontrolled heat losses $\left(\dot{\mathrm{Q}}_{\mathrm{ul}}\right)$ are not readily quantifiable energy outputs. Such heat losses occur at a kiln inlet and outlet, orifices and fissures in pipelines, fans, burners, etc. Their values can be calculated using equation (4), provided all other enthalpies are known.

The enthalpy released by natural gas combustion $\left(\Delta \dot{\mathrm{H}}_{\mathrm{c}}\right)$ can be calculated as:

$$
\Delta \dot{\mathrm{H}}_{\mathrm{c}}=\dot{\mathrm{m}}_{\mathrm{g}} \cdot \mathrm{h}_{\mathrm{gL}}
$$

where $h_{g L}$ is natural gas combustion enthalpy (see $h_{g L}$ value in table 1$)$. The enthalpy change involved in the physico-chemical transformations $\left(\Delta \dot{\mathrm{H}}_{\mathrm{r}}\right)$ was estimated by applying the procedure described elsewhere [57].

There are different options for calculating kiln energy performance. In this study, energy performance was defined as the relationship between the energy put into performing the physico- 
chemical transformations of the ceramic composition and the total energy input into the system.

245 Energy performance can thus be calculated as follows:

$$
\eta(\%)=\frac{\Delta \dot{\mathrm{H}}_{\mathrm{r}}}{\sum_{\mathrm{i}} \dot{\mathrm{H}}_{\mathrm{in,i}}+\Delta \dot{\mathrm{H}}_{\mathrm{c}}} \cdot 100
$$

assuming useful energy to be the energy required to fire the tile composition $\left(\Delta \dot{\mathrm{H}}_{\mathrm{r}}\right)$, i.e. the enthalpy of the physico-chemical transformations of the material being processed.

\subsection{Exergy balance}

The exergy balance of the studied thermal system, taking into account the assumptions set out in

250 Section 3.2, is given by [69]:

$$
\sum_{\mathrm{i}} \dot{\mathrm{A}}_{\mathrm{in}, \mathrm{i}}=\sum_{\mathrm{i}} \dot{\mathrm{A}}_{\text {out }, \mathrm{i}}+\dot{\mathrm{A}}_{\mathrm{r}}-\dot{\mathrm{A}}_{\mathrm{Q}}+\dot{\mathrm{A}}_{\mathrm{D}}
$$

where $\dot{\mathrm{A}}_{\mathrm{in}, \mathrm{i}}$ is the rate of exergy supplied by the input mass flows, $\dot{\mathrm{A}}_{\text {out, } \mathrm{i}}$ is the rate of exergy lost with the output mass flows, the term $\dot{\mathrm{A}}_{\mathrm{r}}$ is the rate of exergy change in the physico-chemical transformations of the ceramic tile and the term $\dot{\mathrm{A}}_{Q}$ is the exergy transfer rate associated with heat fluxes. The term $\dot{A}_{D}$ is the exergy destruction rate in the process. The exergy content of every flow involved in the process was calculated from the equations summarised in table 7. 
Table 7. Exergy flow calculations involved in the exergy balance.

\begin{tabular}{|c|c|c|c|}
\hline Exergy terms & Symbol & Equation & \\
\hline \multirow{5}{*}{$\begin{array}{c}\text { Exergy transfer rates } \\
\text { accompanying the mass flows }\end{array}$} & $\dot{\mathrm{A}}_{\text {in }, \mathrm{i}}, \dot{\mathrm{A}}_{\text {out }, \mathrm{i}}$ & $\dot{\mathrm{A}}_{\mathrm{i}}=\dot{\mathrm{A}}_{\mathrm{ph}, \mathrm{i}}+\dot{\mathrm{A}}_{\mathrm{ch}, \mathrm{i}}$ & $(10)$ \\
\hline & \multirow[b]{2}{*}{$\dot{\mathrm{A}}_{\mathrm{ph}, \mathrm{i}}$} & Physical exergy & \\
\hline & & $\begin{array}{c}\dot{\mathrm{A}}_{\mathrm{ph}, \mathrm{i}}=\left(\dot{\mathrm{H}}-\dot{\mathrm{H}}_{0}\right)-\mathrm{T}_{0}\left(\dot{\mathrm{S}}-\dot{\mathrm{S}}_{0}\right) \\
\left(\dot{\mathrm{H}}-\dot{\mathrm{H}}_{0}\right)=\frac{\dot{\mathrm{m}}_{\mathrm{i}}}{\mathrm{M}_{\mathrm{i}}} \cdot\left[\overline{\mathrm{c}}_{\mathrm{pi}} \cdot\left(\mathrm{T}-\mathrm{T}_{0}\right)\right] \\
\left(\dot{\mathrm{S}}-\dot{\mathrm{S}}_{0}\right)=\frac{\dot{\mathrm{m}}_{\mathrm{i}}}{\mathrm{M}_{\mathrm{i}}} \cdot\left[\overline{\mathrm{c}}_{\mathrm{pi}} \cdot \ln \left(\frac{\mathrm{T}}{\mathrm{T}_{0}}\right)-\overline{\mathrm{R}} \cdot \ln \left(\frac{\mathrm{P}}{\mathrm{P}_{0}}\right)\right]\end{array}$ & $\begin{array}{l}(11) \\
(12) \\
(13)\end{array}$ \\
\hline & \multirow[b]{2}{*}{$\dot{\mathrm{A}}_{\mathrm{ch}, \mathrm{i}}$} & \multicolumn{2}{|l|}{ Chemical exergy } \\
\hline & & $\begin{array}{c}\dot{\mathrm{A}}_{\mathrm{ch}, \mathrm{i}}=\frac{\dot{\mathrm{m}}_{\mathrm{i}}}{\mathrm{M}_{\mathrm{i}}} \cdot \overline{\mathrm{a}}_{\mathrm{chi}} \\
\overline{\mathrm{a}}_{\mathrm{chi}}=\sum_{\mathrm{j}} \mathrm{y}_{\mathrm{j}} \cdot\left(\overline{\mathrm{a}}_{\mathrm{ch}, \mathrm{j}}+\overline{\mathrm{R}} \mathrm{T}_{0} \ln \mathrm{y}_{\mathrm{j}}\right)\end{array}$ & $\begin{array}{l}(14) \\
(15)\end{array}$ \\
\hline $\begin{array}{l}\text { Exergy change rate in a physico- } \\
\text { chemical transformation } \\
\qquad \mathbf{M}+\mathbf{N} \rightarrow \mathbf{P}\end{array}$ & $\dot{\mathrm{A}}_{\mathrm{r}}$ & $\dot{\mathrm{A}}_{\mathrm{r}}=\dot{\mathrm{A}}_{\mathrm{ch}, \mathrm{M}}+\dot{\mathrm{A}}_{\mathrm{ch}, \mathrm{N}}-\dot{\mathrm{A}}_{\mathrm{ch}, \mathrm{P}}=\Delta \dot{\mathrm{G}}^{0}$ & $(16)$ \\
\hline $\begin{array}{l}\text { Exergy transfer rate during heat } \\
\qquad \operatorname{loss}\end{array}$ & $\dot{\mathrm{A}}_{\mathrm{Q}}$ & $\begin{array}{c}\dot{\mathrm{A}}_{\mathrm{Q}}=\sum\left(1-\frac{\mathrm{T}_{0}}{\mathrm{~T}_{\mathrm{Q}}}\right) \cdot \dot{\mathrm{Q}}_{\mathrm{Q}} \\
\dot{\mathrm{A}}_{\mathrm{Q}}=\dot{\mathrm{A}}_{\mathrm{w}}+\dot{\mathrm{A}}_{\mathrm{ul}} \\
\dot{\mathrm{A}}_{\mathrm{Q}}=\left(1-\frac{\mathrm{T}_{0}}{\mathrm{~T}_{\mathrm{w}}}\right) \cdot \dot{\mathrm{Q}}_{\mathrm{w}}+\left(1-\frac{\mathrm{T}_{0}}{\mathrm{~T}_{\mathrm{ul}}}\right) \cdot \dot{\mathrm{Q}}_{\mathrm{ul}}\end{array}$ & $\begin{array}{l}(17) \\
(18) \\
(19)\end{array}$ \\
\hline Exergy destruction rate & $\dot{\mathrm{A}}_{\mathrm{D}}$ & $\dot{\mathrm{A}}_{\mathrm{D}}=\mathrm{T}_{0} \cdot \dot{\sigma}$ & (20) \\
\hline Exergy efficiency & $\eta_{\dot{A}}$ & $\eta_{\dot{A}}(\%)=\frac{\dot{\mathrm{A}}_{\mathrm{r}}}{\sum_{\mathrm{i}} \dot{\mathrm{A}}_{\mathrm{in}, \mathrm{i}}} \cdot 100$ & (21) \\
\hline
\end{tabular}

As shown in table 7, the exergy content of a mass flow can be split into two contributions: physical exergy $\left(\dot{\mathrm{A}}_{\text {ph }}\right)$ and chemical exergy $\left(\dot{\mathrm{A}}_{\mathrm{ch}}\right)$. The physical exergy of a mass flow is given by equation

260 (11), where $\left(\dot{\mathrm{H}}-\dot{\mathrm{H}}_{0}\right)$ is the rate of enthalpy change, and $\left(\dot{\mathrm{S}}-\dot{\mathrm{S}}_{0}\right)$ is the rate of entropy change, which can be obtained from thermodynamic tables [65] at their corresponding temperature, T, and pressure, $\mathrm{P}$, taking into account the reference environment [63][64]. Assuming specific heat to be assumed constant, equations (12) and (13) can be used to obtain the enthalpy and entropy changes. The pressure term on the right side of equation (13) applies only for calculating the entropy when 265 the fluid is an ideal gas. It is absent for liquids and solids. In the present study, the pressure term was not taken into account for gases, because all gases involved in the firing process were assumed to be at atmospheric pressure $\left(\mathrm{P}=\mathrm{P}_{0}\right)$. 
The chemical exergy rate of a flow is given by equation (14), where $\dot{\mathrm{m}}_{\mathrm{i}}(\mathrm{kg} / \mathrm{s})$ is the mass flow rate and $\mathrm{a}_{\text {chi }}$ its molar chemical exergy. For an ideal gas mixture, the molar chemical exergy $\left(\overline{\mathrm{a}}_{\text {chi }}\right)$ is given by equation (15), where $y_{j}$ is the mole fraction of component $\mathrm{j}$, and $\overline{\mathrm{a}}_{\mathrm{ch}, \mathrm{j}}$ its standard molar chemical exergy. The chemical exergy of gaseous fuels may be estimated by using this equation [70][71]. The change in chemical exergy of substances participating in a reaction such as $\mathrm{M}+\mathrm{N}$ $\rightarrow \mathrm{P}$ is related to the Gibbs free energy of the reaction $\Delta \mathrm{G}^{0}$ by equation (16).

The exergy rate involved in the heat lost through the hot kiln surfaces, $\dot{A}_{Q}$, was associated with

275 the heat flow $\dot{\mathrm{Q}}_{\mathrm{Q}}$ at temperature $\mathrm{T}_{\mathrm{Q}}$ using the environment temperature $\mathrm{T}_{0}$ as reference [69], and is given by equation (17).

The term $\dot{A}_{D}$ represents the exergy destruction rate owing to the system's internal irreversibilities, given by equation (20), in accordance with the Gouy-Stodola law [72], which establishes that the rate of exergy destruction is proportional to the product of the reference temperature $\left(\mathrm{T}_{0}\right)$ and the rate of entropy generation ( $\dot{\sigma})$ within a system. Particularising equation (9) to the input and output streams of the studied kiln, the following exergy balance equation was obtained:

$$
\dot{\mathrm{A}}_{\mathrm{D}}=\left(\dot{\mathrm{A}}_{\mathrm{g}}+\dot{\mathrm{A}}_{\mathrm{ox}}+\dot{\mathrm{A}}_{\mathrm{ca}}+\dot{\mathrm{A}}_{\mathrm{d}}+\dot{\mathrm{A}}_{\mathrm{u}}\right)-\left(\dot{\mathrm{A}}_{\mathrm{fg}}+\dot{\mathrm{A}}_{\mathrm{r}}+\dot{\mathrm{A}}_{\mathrm{f}}+\dot{\mathrm{A}}_{\mathrm{cg}}\right)+\dot{\mathrm{A}}_{\mathrm{w}}+\dot{\mathrm{A}}_{\mathrm{ul}}
$$

where the exergy balance in the kiln comprised the input exergy flows of natural gas, oxidising air, cooling air, dilution air, and unfired porcelain tiles and the output exergy flows of the flue gases, physico-chemical reactions, fired porcelain tiles, cooling exhaust gases, kiln wall heat losses, and uncontrolled heat losses.

The literature contains many definitions of exergy efficiency [20][21][23][29][40][41][42]. In this study, exergy efficiency is defined as the ratio of the useful exergy for the firing process to the total exergy input into the process $\left(\sum_{\mathrm{i}} \dot{\mathrm{A}}_{\mathrm{in}, \mathrm{i}}\right)$, where useful exergy is the chemical exergy required to develop the necessary physico-chemical transformations during porcelain tile firing $\left(\dot{\mathrm{A}}_{\mathrm{r}}\right)$, this being the targeted system output. Thus, studied kiln exergy efficiency may be expressed as equation (21). 


\section{Results and discussion}

This section discusses the results of the mass and energy balance of the studied industrial tile kiln.

\subsection{Mass balance}

Table 8 details the properties of the streams involved in the mass balance.

Table 8. Characteristics of the kiln input and output flows.

\begin{tabular}{|c|c|c|c|c|c|c|c|}
\hline \multicolumn{3}{|c|}{ Flow } & Symbols & $\mathbf{T}(\mathbf{K})$ & $\begin{array}{c}c_{p i} \\
(k J / k g ~ K)\end{array}$ & $\underset{(\mathrm{kg} / \mathrm{s})}{\dot{\mathbf{m}}_{\mathbf{i}}}$ & $\begin{array}{c}\text { Contribution } \\
(\%)\end{array}$ \\
\hline \multirow{6}{*}{ Inputs } & \multicolumn{2}{|c|}{ Natural gas } & $\dot{\mathrm{m}}_{\mathrm{g}}$ & 306.3 & 2.152 & 0.092 & 0.45 \\
\hline & \multicolumn{2}{|c|}{ Oxidising air } & $\dot{\mathrm{m}}_{\mathrm{ox}}$ & 306.3 & 1.005 & 2.159 & 10.48 \\
\hline & \multicolumn{2}{|c|}{ Cooling air } & $\dot{\mathrm{m}}_{\mathrm{ca}}$ & 306.3 & 1.005 & 13.272 & 64.41 \\
\hline & \multicolumn{2}{|c|}{ Dilution air } & $\dot{\mathrm{m}}_{\mathrm{d}}$ & 306.3 & 1.005 & 2.860 & 13.88 \\
\hline & \multirow{2}{*}{ Unfired tiles } & Dry solid & $\dot{\mathrm{m}}_{\mathrm{u}}$ & 328.5 & 0.751 & 2.215 & 10.75 \\
\hline & & $\mathrm{H}_{2} \mathrm{O}$ & $\dot{\mathrm{m}}_{\mathrm{H} 2 \mathrm{O}}$ & 328.5 & 4.182 & 0.0068 & 0.03 \\
\hline & \multicolumn{5}{|c|}{ TOTAL } & 20.60 & 100 \\
\hline \multirow{4}{*}{ Outputs } & \multicolumn{2}{|c|}{ Flue gases } & $\dot{\mathrm{m}}_{\mathrm{fg}}$ & 511.8 & 0.988 & 5.189 & 25.19 \\
\hline & \multicolumn{2}{|c|}{ Fired tiles } & $\dot{\mathrm{m}}_{\mathrm{f}}$ & 387.4 & 0.762 & 2.144 & 10.41 \\
\hline & \multicolumn{2}{|c|}{ Cooling exhaust gases } & $\dot{\mathrm{m}}_{\mathrm{cg}}$ & 425.0 & 1.005 & 13.272 & 64.41 \\
\hline & \multicolumn{2}{|c|}{ TOTAL } & & & & 20.60 & 100 \\
\hline
\end{tabular}

The gas flow rates (air gas streams and flue gas stream) were determined with an S-type pitot tube according to standard UNE 77225:2000. The natural gas flow rate was obtained from the direct readout of the flowmeter installed in the kiln over time periods longer than 3 hours. Natural gas pressure and temperature in the duct were also recorded. These data enabled the gas flow rate to be normalised. The mass flow rate of the ceramic material being processed was determined experimentally, counting the tiles that entered the kiln in a given period. Subsequently, the mass of at least ten tiles was determined at the kiln entrance and exit, averaging the values in each case. Tile moisture at the kiln entrance was determined by measuring the difference in weight between the unfired tile before and after drying to constant weight in a lab dryer at $110{ }^{\circ} \mathrm{C}$.

310 From table 8 it may be noted that the total mass flow circulating in the kiln was $20.60 \mathrm{~kg} / \mathrm{s}$, the ratio of the gaseous to solid streams being 9:1. That is, ceramic tile only accounted for $10 \%$ of the overall mass flow in the kiln. The amount of air (including oxidising, dilution, and cooling air) 
used in the kiln accounted for the largest mass flow. In particular, the external ambient air intake to cool the material accounted for $64 \%$ of the total input mass flow, yielding a ratio of $6.2 \mathrm{~kg}$

315 cooling air/kg fired tile. Further to be noted was the high dilution air mass flow intake into the first part of the kiln. This air was fed in for two reasons: 1) to increase oxygen content in the kiln and 2) to reduce flue gas temperature, which must not exceed the maximum operating temperature (usually about $200-250{ }^{\circ} \mathrm{C}$ ) of the exhaust fan. 


\subsection{Energy balance}

325 Figure 6 depicts the values of the experimental variables measured in the streams involved in the energy balance and their energy content.

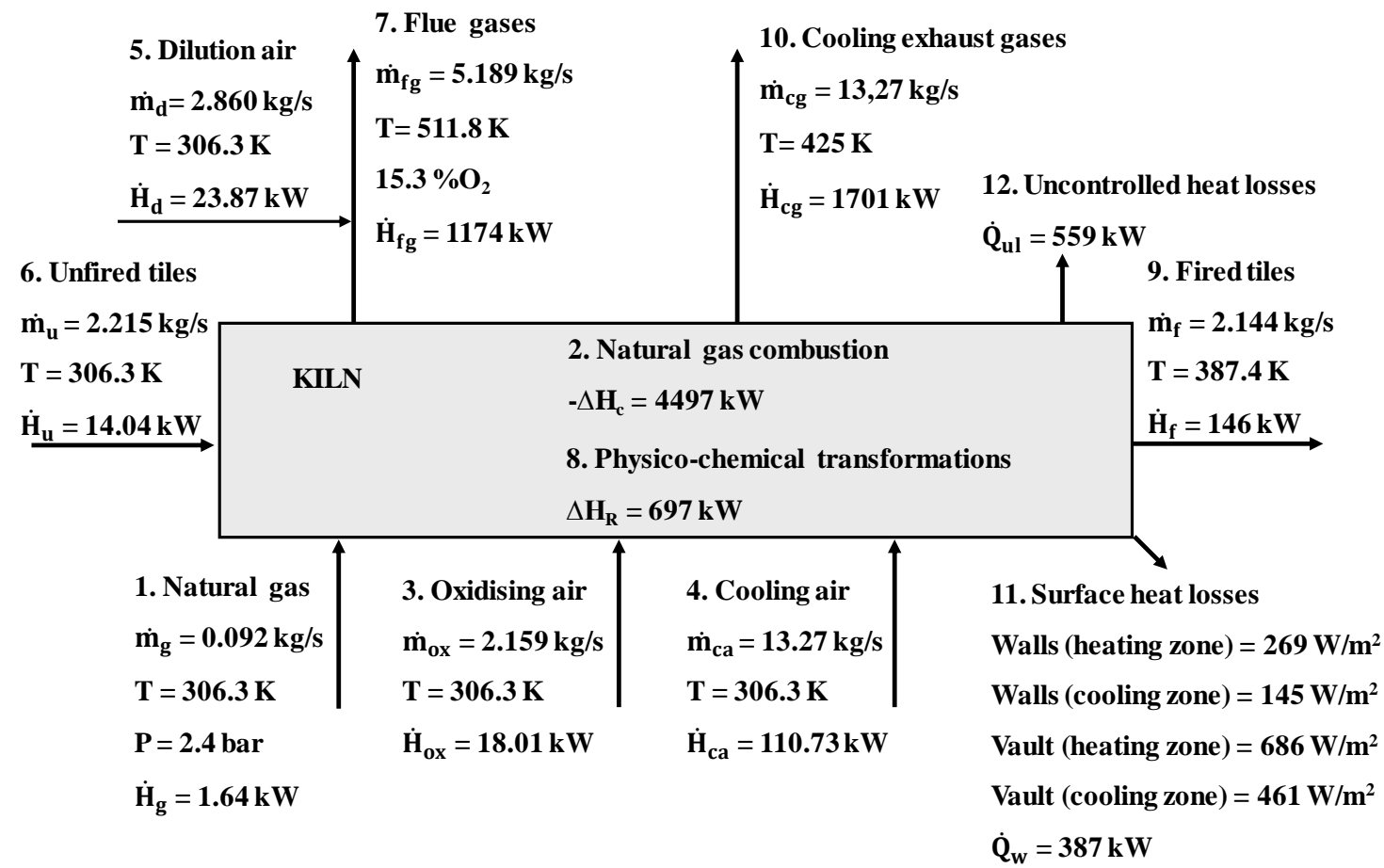

Figure 6. Values of the streams measured in the studied kiln energy balance.

330 The enthalpies of each energy flow and their percentage contribution to the energy balance are shown in table 9. The numbers in parenthesis refer to the flow numbers in figure 6. 
Table 9. Results of the energy balance.

\begin{tabular}{|c|c|c|c|c|}
\hline \multicolumn{2}{|r|}{ Flow } & Symbol & Energy rate & $\begin{array}{l}\text { Percentage } \\
\text { Contribution }\end{array}$ \\
\hline \multirow{7}{*}{ Inputs } & (1) Natural gas & $\dot{\mathrm{H}}_{\mathrm{g}}$ & 1.64 & 0.04 \\
\hline & (2) Natural gas combustion & $\Delta \dot{\mathrm{H}}_{\mathrm{c}}$ & 4497 & 96.39 \\
\hline & (3) Oxidising air & $\dot{\mathrm{H}}_{\mathrm{ox}}$ & 18.01 & 0.39 \\
\hline & (4) Cooling air & $\dot{\mathrm{H}}_{\mathrm{ca}}$ & 23.87 & 0.51 \\
\hline & (5) Dilution air & $\dot{\mathrm{H}}_{\mathrm{d}}$ & 110.73 & 2.37 \\
\hline & (6) Unfired tiles & $\dot{\mathrm{H}}_{\mathrm{u}}$ & 14.04 & 0.30 \\
\hline & TOTAL & --- & 4665.31 & 100 \\
\hline \multirow{7}{*}{ Outputs } & (7) Flue gases & $\dot{\mathrm{H}}_{\mathrm{fg}}$ & 1174.20 & 25.17 \\
\hline & (8) Physico-chemical transformations & $\Delta \dot{\mathrm{H}}_{\mathrm{r}}$ & 697.31 & 14.95 \\
\hline & (9) Fired tiles & $\dot{\mathrm{H}}_{\mathrm{f}}$ & 145.95 & 3.13 \\
\hline & (10) Cooling exhaust gases & $\dot{\mathrm{H}}_{\mathrm{cg}}$ & 1700.63 & 36.45 \\
\hline & (11) Surface heat losses & $\dot{\mathrm{Q}}_{\mathrm{w}}$ & 387.98 & 8.32 \\
\hline & (12) Uncontrolled heat losses & $\dot{\mathrm{Q}}_{\mathrm{ul}}$ & 559.25 & 12.00 \\
\hline & TOTAL & --- & 4665.31 & 100 \\
\hline
\end{tabular}

Figure 7 shows the Sankey diagram visualising the energy balance detailed in table 9 .
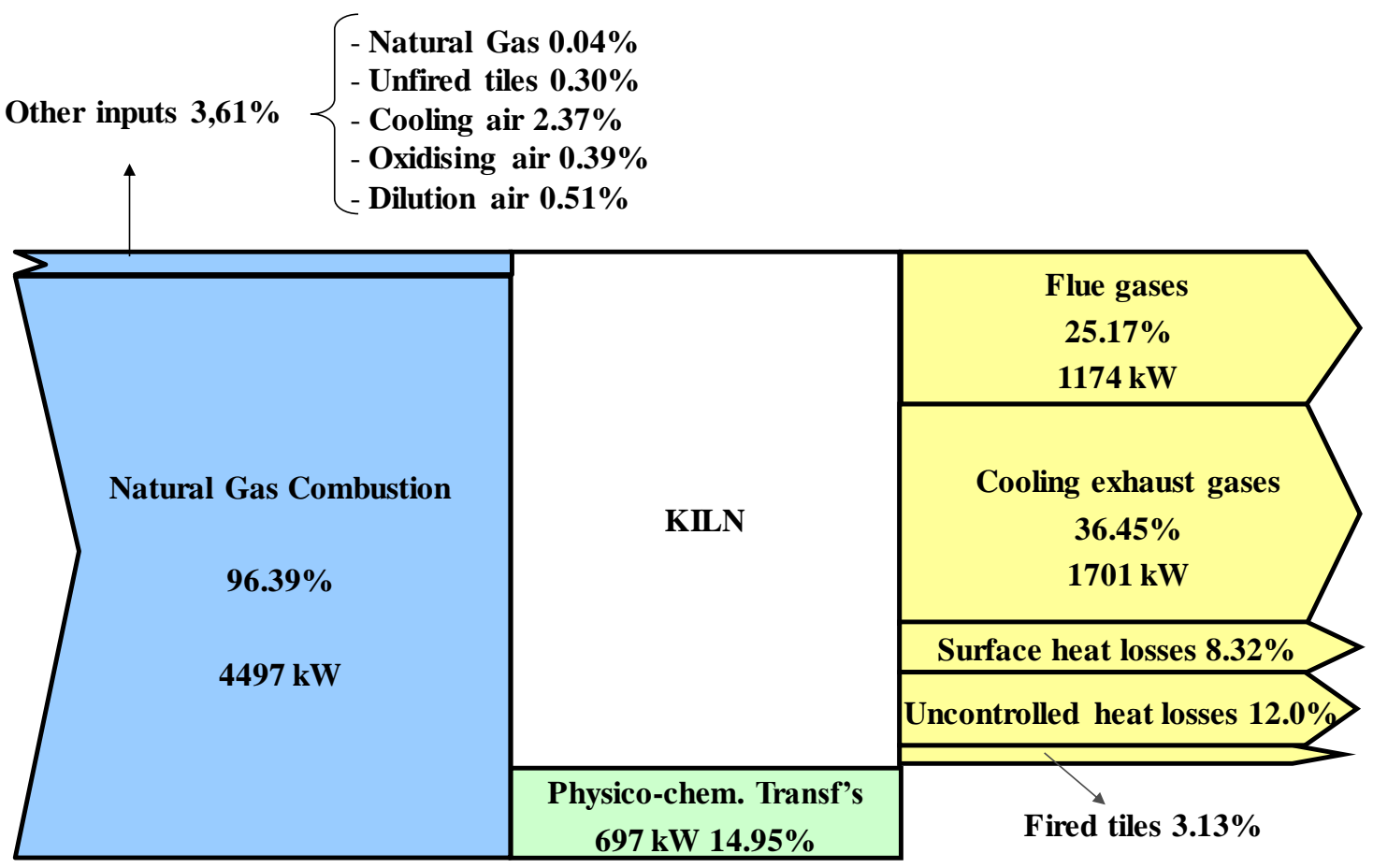

Figure 7. Energy Sankey diagram. 
The following may be concluded from table 9 , figure 6 , and figure 7 :

- Studied kiln thermal energy consumption was about $4665 \mathrm{~kW}$. The main energy source of the process was obviously natural gas combustion, which accounted for $96 \%$ of the total energy input into the kiln. This was the sole energy contribution that constituted an economic cost for the company.

- The other energy inputs were provided by the flows that entered the kiln at low temperature: unfired porcelain tiles $(0.30 \%)$, cooling air $(2.37 \%)$, oxidising air $(0.39 \%)$, and dilution air $(0.51 \%)$. About $15 \%$ of the energy input was used in the targeted physico-chemical transformations of the ceramic tile composition. Although porcelain tile is a semi-vitreous tile, which has a peak firing temperature of about $1190{ }^{\circ} \mathrm{C}$ and firing cycle that lasts almost an hour, this $15 \%$ energy input used in the chemical reactions was relatively small compared to the total energy input into the kiln.

- The experimental measurements made in the kiln revealed that the total thermal energy lost through the flue and cooling exhaust gas stacks was about $2875 \mathrm{~kW}: 25 \%$ of the energy input was lost through the flue gas stack, while $36 \%$ was lost through the cooling exhaust gas stack. This was more than $61 \%$ of kiln energy consumption. Improving kiln energy performance therefore requires minimising and/or recovering such heat losses by implementing flue and cooling gas heat recovery systems and optimising oxidising air flow rates.

- Energy losses through kiln surfaces (8\%) and so-called uncontrolled heat losses (12\%) were significant. These losses show that the kiln thermal insulation was unable to prevent almost $20 \%$ of the total energy input into the studied kiln from being lost. The quality of kiln thermal insulation therefore needs to be improved.

If useful energy is assumed to be the energy required to fire the porcelain tile composition $\left(\Delta \dot{\mathrm{H}}_{\mathrm{r}}\right)$, i.e. the enthalpy of the physico-chemical reactions of the material being processed, kiln energy performance, according to equation (8), was therefore $15 \%$. 
Regarding kiln production (table 6), kiln specific energy consumption was $583 \mathrm{kWh} / \mathrm{t}$ fired tile 365 relative to the $\mathrm{LHV}\left(14.86 \mathrm{kWh} / \mathrm{m}^{2}\right.$ fired tile), and the $\mathrm{CO}_{2}$ emission was $118 \mathrm{~kg} \mathrm{CO} / \mathrm{t}$ fired tile (3.02 $\mathrm{kg} \mathrm{CO}_{2} / \mathrm{m}^{2}$ fired tile). 


\subsection{Exergy balance}

The exergies of each stream and their (percentage) contribution to the exergy balance are shown

Table 10. Results of the exergy balance.

\begin{tabular}{|c|c|c|c|c|c|c|}
\hline \multicolumn{2}{|r|}{ Flow } & Symbol & $\begin{array}{c}\text { Physical } \\
\text { exergy }\end{array}$ & $\begin{array}{c}\text { Chemical } \\
\text { exergy }\end{array}$ & $\begin{array}{c}\text { Total } \\
\text { exergy }\end{array}$ & Contribution \\
\hline \multirow{6}{*}{ Inputs } & (1) Natural Gas & $\dot{\mathrm{A}}_{\mathrm{g}}$ & - & 4669 & 4669 & 99.95 \\
\hline & (2) Oxidising air & $\dot{\mathrm{A}}_{\mathrm{ox}}$ & 0.26 & - & 0.26 & 0.01 \\
\hline & (3) Cooling air & $\dot{\mathrm{A}}_{\mathrm{ca}}$ & 1.60 & - & 1.60 & 0.03 \\
\hline & (4) Dilution air & $\dot{\mathrm{A}}_{\mathrm{d}}$ & 0.34 & - & 0.34 & 0.01 \\
\hline & (5) Unfired tiles & $\dot{\mathrm{A}}_{\mathrm{u}}$ & 0.19 & - & 0.19 & 0.00 \\
\hline & TOTAL & --- & 2.39 & 4669 & 4671 & 100 \\
\hline \multirow{6}{*}{ Outputs } & (6) Flue gases & $\dot{\mathrm{A}}_{\mathrm{fg}}$ & 291 & 80 & 371 & 7.94 \\
\hline & (7) Fired tiles & $\dot{\mathrm{A}}_{\mathrm{f}}$ & 18 & - & 18 & 0.39 \\
\hline & $\begin{array}{c}\text { (9) Cooling exhaust } \\
\text { gases }\end{array}$ & $\dot{\mathrm{A}}_{\mathrm{ca}}$ & 286 & - & 286 & 6.13 \\
\hline & $\begin{array}{l}\text { (10) Surface heat } \\
\text { losses }\end{array}$ & $\dot{\mathrm{A}}_{\mathrm{w}}$ & 50 & - & 50 & 1.06 \\
\hline & $\begin{array}{l}\text { (11) Uncontrolled } \\
\text { heat losses }\end{array}$ & $\dot{\mathrm{A}}_{\mathrm{ul}}$ & 63 & - & 63 & 1.35 \\
\hline & TOTAL & --- & 708 & 80 & 788 & 17 \\
\hline \multirow{3}{*}{$\begin{array}{c}\text { Exergy } \\
\text { destroyed } \\
\text { inside the } \\
\text { kiln }\end{array}$} & $\begin{array}{l}\text { (8) Physico- } \\
\text { chemical } \\
\text { transformations }\end{array}$ & $\dot{\mathrm{A}}_{\mathrm{r}}$ & - & 456 & 456 & 10 \\
\hline & $\begin{array}{c}\text { Other kiln } \\
\text { irreversibilities }\end{array}$ & - & - & - & 3427 & 73 \\
\hline & TOTAL & $\dot{\mathrm{A}}_{\mathrm{D}}$ & - & - & 3883 & 83 \\
\hline
\end{tabular}

A Sankey flow diagram to better visualise the data detailed in table 10 is shown in figure 8 . 


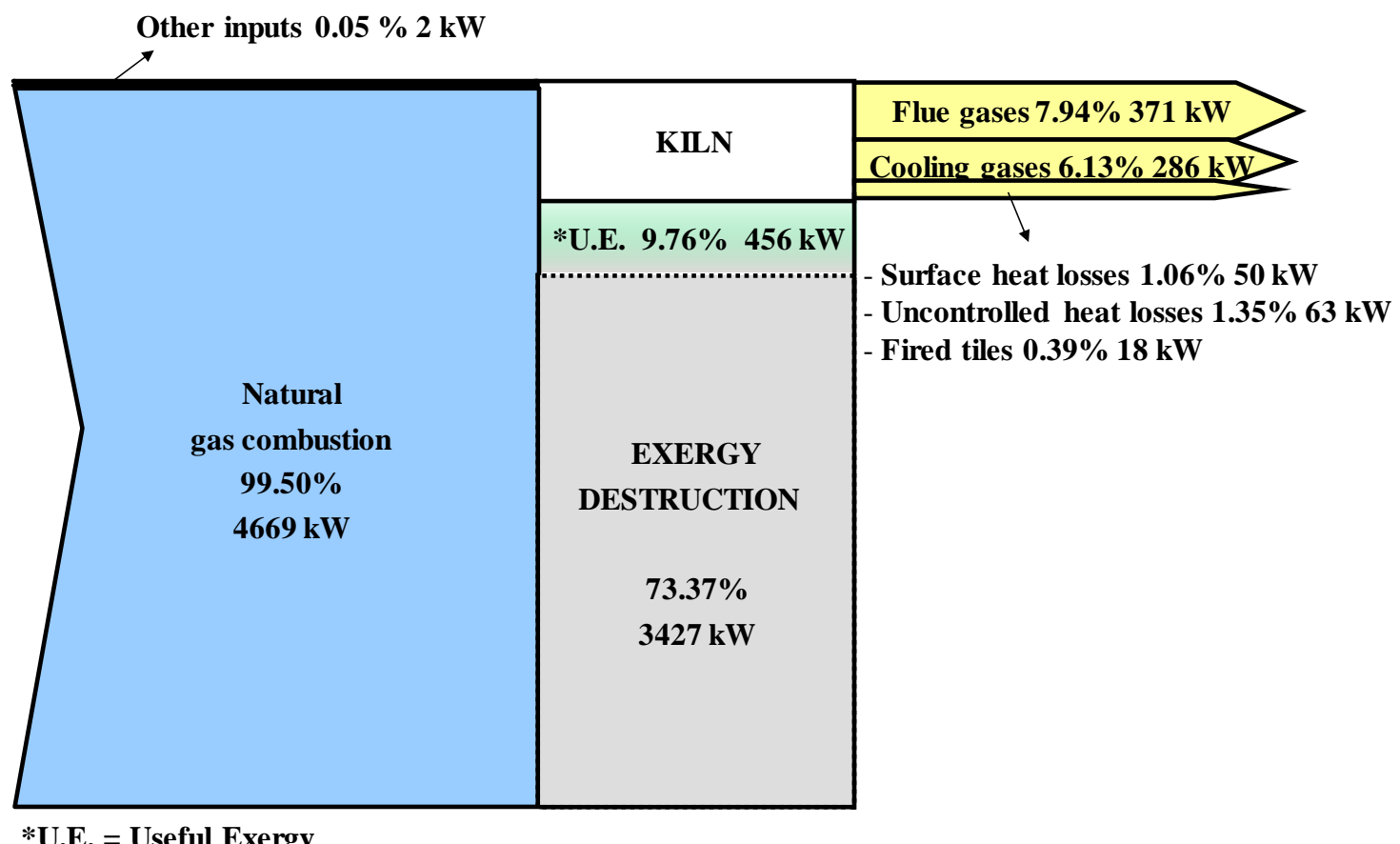

Figure 8. Exergy Sankey diagram.

The discussion in Section 4.2 shows that the application of the first law of thermodynamics can provide a useful view of kiln efficiency. However, the resulting energy balance misses an important aspect of kiln efficiency relating to the quality or usefulness of the energy inputs and outputs. In contrast, exergy analysis focuses on this latter aspect and allows the relative importance of the irreversibilities present in the different subsystems into which the kiln can be divided, or the exergy losses associated with these, to be estimated. In this regard, the data in table 10 and figure 8 allow the following conclusions to be drawn:

- The main exergy input source was natural gas combustion (4669 kW). Part of this exergy was used for the targeted physico-chemical transformations of the porcelain tile composition. In the studied kiln, the useful exergy used in the physico-chemical transformations of the tile composition in firing was $10 \%$.

- Most of the exergy was destroyed because of the irreversibilities present in the kiln. The kiln overall exergy destruction rate was $3883 \mathrm{~kW}(83 \%)$.

- Application of the Gouy-Stodola law allows detailed identification of the subsystems in which exergy was destroyed. These subsystems are illustrated in Figure 9. 


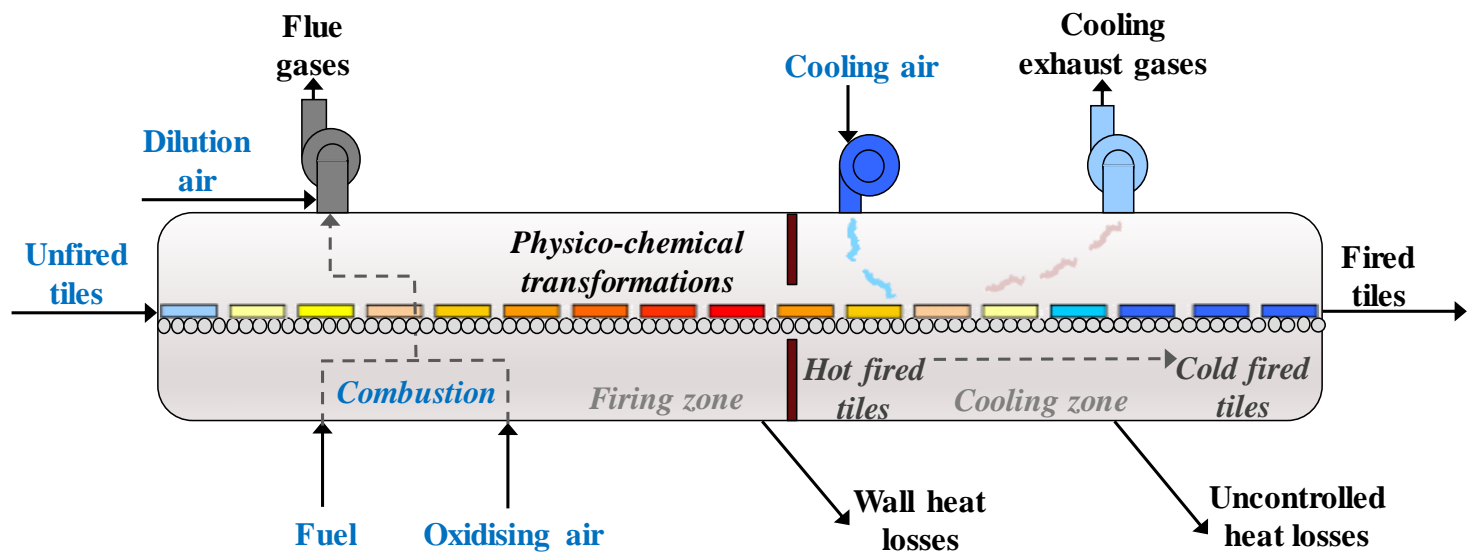

Figure 9. Location of the kiln subsystems in which exergy was destroyed.

- The exergy destroyed in each of the identified subsystems is shown in table 11.

Table 11. Location of the irreversibilities in the kiln.

\begin{tabular}{|c|c|c|c|c|}
\hline $\begin{array}{c}\text { Source of } \\
\text { irreversibilities }\end{array}$ & Subsystems & $\begin{array}{c}\text { Exergy destroyed } \\
(\mathrm{kW})\end{array}$ & \multicolumn{2}{|c|}{ Percentage (\%) } \\
\hline \multirow{2}{*}{ Chemical reactions } & $\begin{array}{l}\text { Natural gas } \\
\text { combustion }\end{array}$ & 1573 & 41 & \multirow[b]{2}{*}{53} \\
\hline & $\begin{array}{l}\text { (8) Physico-chemical } \\
\text { transformations - } \dot{A}_{r} \\
\text { - Useful exergy }\end{array}$ & 456 & 12 & \\
\hline \multirow{3}{*}{ Heat transfer } & $\begin{array}{l}\text { Heat exchange } \\
\text { process during tile } \\
\text { cooling }\end{array}$ & 825 & 21 & \multirow{3}{*}{47} \\
\hline & $\begin{array}{c}\text { External surfaces } \\
\text { and uncontrolled } \\
\text { heat losses }\end{array}$ & 818 & 21 & \\
\hline & $\begin{array}{l}\text { Flue gas dilution } \\
\text { before gas exhaust }\end{array}$ & 211 & 5 & \\
\hline \multicolumn{2}{|c|}{ TOTAL } & 3883 & \multicolumn{2}{|c|}{100} \\
\hline
\end{tabular}

- The values in table 11 show that the chemical reactions that developed in firing led to 53\% exergy destruction.

- Natural gas combustion was the main irreversibility in the kiln, accounting for $41 \%$ of total irreversibilities. This indicates that a substantial portion of natural gas exergy (34\%) was destroyed during the combustion process. No more than $66 \%$ could therefore be transferred to the tile composition. The useful work required for the firing process was drawn from this exergy fraction of the fuel. Current technology and energy costs make the use of combustion 
in ceramic tile roller kilns unavoidable. A significant reduction in combustion irreversibility by conventional means can therefore simply not be expected in the short term [73].

- Much of the exergy input into the kiln, namely $21 \%$ of total irreversibilities, was destroyed during tile cooling owing to heat transfer between the external ambient cooling air fed into the kiln and the hot tile. The results obtained suggest that reducing exergy losses in the cooling zone could significantly improve exergy efficiency in this type of kiln, if the residual exergy were recovered (e.g. to the dryers) and/or used as useful work by means of appropriate turbines. The possible optimisation of this cooling process is further analysed in Section 5.2.

- Of all the exergy input into the kiln, $21 \%$ was destroyed by heat transfer through kiln surfaces as well as by uncontrolled heat losses. This suggests that kiln thermal insulation should be 415 improved to reduce exergy losses.

- The physico-chemical transformations of the tile composition being processed accounted for $12 \%$ of total irreversibilities.

- Finally, part of the exergy, accounting for 5\% of total irreversibilities, was destroyed owing to the dilution air fed in at the kiln entrance to lower exhaust flue gas temperature, which must not exceed the maximum operating temperature of the exhaust fan. In this part of the kiln, instead of taking in external ambient air to lower the flue gas temperature, a heat exchanger could be installed to recover, instead of destroying, this exergy.

The streams having chemical exergy values were the natural gas, flue gas, and ceramic tile streams. They only had significant values for processes whose associated chemical reactions had large reaction enthalpies, in this case the natural gas combustion reaction. This explains why many studies in the literature on processed products similar to ceramic materials [21][40] have only considered the chemical exergy introduced with the fuel, neglecting the exergy involved in processing the materials. However, the exergy consumed in generating the required physicochemical transformations of the porcelain tile composition was the most important exergy consumption because it defined kiln exergy efficiency.

Finally, assuming the kiln to be an isolated system, kiln exergy efficiency amounted to $10 \%$. The exergy destroyed by irreversibilities was unrecoverable, but the remaining exergy (17\%), in the 
form of waste heat, was potentially recoverable (at least partially) to secondary facilities or to the kiln itself. It would therefore be of interest to ascertain its value for system improvement. If the remaining exergy were recovered, the studied kiln's potential energy efficiency could theoretically amount to $27 \%$. It would therefore be interesting to investigate more complex systems (e.g. kiln + dryer) in future studies.

\section{Analysis of improvement measures based on optimisation actions}

The above analysis suggests that kiln energy efficiency could be improved by essentially two types of measures: those requiring investments and those based on a better management of the facility at issue. The first measures involve implementation of heat recovery systems from flue and cooling gases using heat exchangers; replacement of current burners with burners that work at lower air pressures; preheating of the oxidising air; improvement of kiln thermal insulation by reducing insulation thermal conductivity or increasing insulation thickness; and identification of

445 potential defects in the thermal sealing of kiln roller holders. The second measures require appropriately setting the key kiln parameters to optimise kiln working conditions.

The results obtained in the energy and exergy balances drawn up indicate that the main factors to be addressed in order to improve kiln energy and exergy performance are optimisation of the cooling air ratio and optimisation of the oxidising air flow rate used for combustion. These two

450 factors are largely dependent on kiln operating conditions and can be addressed without additional investments. Both factors are analysed in detail below.

\subsection{Optimising excess oxidising air}

Kiln burners usually run with significant excess air in order to generate a suitable amount of oxygen in the flue gases for appropriate development of the oxidation reactions of the organic matter in the tile composition. Reducing air flow will lower natural gas consumption, as the temperature of a lower amount of air needs to be raised, in turn reducing energy losses in the flue gas exhaust stack. However, applying this cost-saving measure is conditioned by the need to assure sufficient oxidising air feed into the firing zone. This oxidising air feed must supply at least enough oxygen to maintain product quality and stability. It was experimentally determined in the 
study that the excess air ratio needed to be 1.40 . This value is considered high, as $40 \%$ more than the amount of air required to carry out stoichiometric combustion was being fed into the kiln. To improve energy efficiency, it would be recommendable to reduce the oxidising air flow to values between 1.05 and 1.10 .

Assuming a control volume comprising natural gas and oxidising air inputs and flue gas outputs operating in steady state under adiabatic conditions and considering combustion at different excess air ratios, the corresponding adiabatic flame temperature was estimated by an energy balance, thus obtaining the exergy destruction under different conditions. This is shown in figure 10.

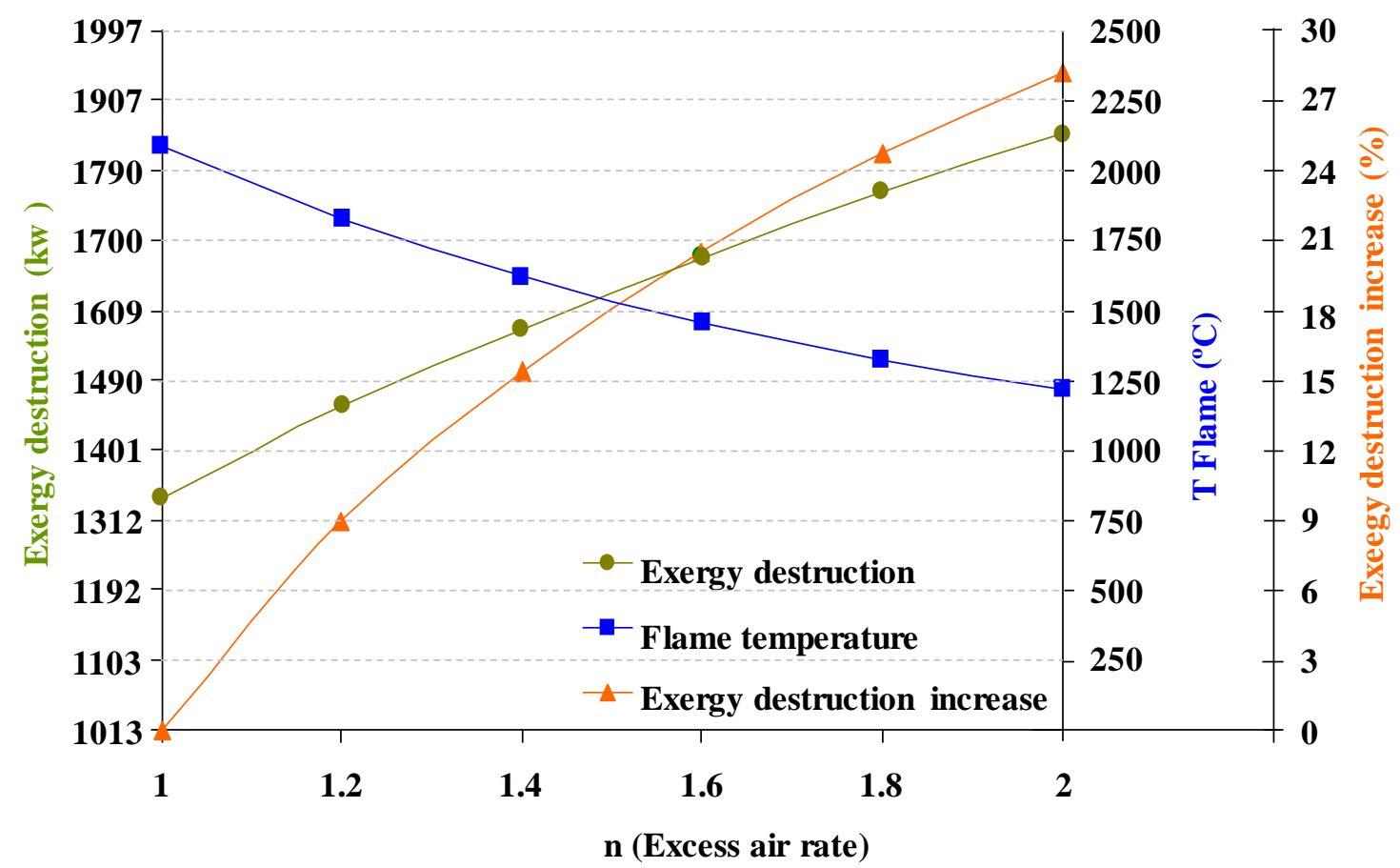

Figure 10. Exergy destruction rate, increase with respect to the stoichiometric air ratio, and adiabatic flame temperature as a function of excess air rate.

The results show that operating at the stochiometric air ratio, the exergy destruction rate would minimise. Increasing the excess air rate in combustion would decrease the adiabatic flame temperature but increase the exergy destruction rate. Under standard operating conditions of the 475 studied kiln (stochiometric ratio $=1.4$ ), the exergy destruction generated was $15 \%$ higher than that obtained with stoichiometric combustion. This indicates that, from an energy quality point of view, it would be convenient to operate with minimum excess air (i.e. at a stochiometric ratio of about 1.05-1.10), provided this is compatible with other system constraints, in order to decrease 
combustion system irreversibilities, increase combustion exergy efficiency, and consequently enhance kiln energy efficiency. In addition, decreasing combustion air flow would reduce the flue gas stream, so that kiln energy losses caused by flue gas exhaust would decrease.

\subsection{Optimising the cooling air ratio}

To cool the fired ceramic tiles, external ambient air needed to be fed into the kiln to exchange heat with the hot tiles. It would be possible either to recover cooling exhaust gas energy to the kiln itself to preheat the oxidising air or to recover this energy to other plant facilities such as the dryers, by implementing energy saving actions and thus reducing dryer energy consumption. In the studied kiln, the cooling gases had a high flow rate: cooling gas temperature was $425 \mathrm{~K}$ and energy content was $1701 \mathrm{~kW}$. Currently, in ceramic tile kilns, cooling exhaust gas waste heat is usually recovered, as such gases are made up of pollutant-free air. In any event, waste heat recovery of the studied kiln cooling exhaust gases would decrease kiln energy consumption and raise overall energy efficiency of the kiln and the plant.

The specific airflow used for cooling depends on kiln design (length of the cooling zone, air-totile contact system, etc.). Kiln operation can therefore take place at different specific mass flows (kg cooling air/kg fired tile). Figure 11 shows the change in exergy destruction rate in the kiln cooling zone with the air-fired tile ratio for fired tile cooling. Figure 12 shows the rise in cooling gas exergy content in the kiln cooling zone with the air-fired tile ratio for fired tile cooling. It was hereby assumed that the cooling exhaust gas stream enthalpy remained constant (1701 kW); the gas temperature was recalculated assuming the fired tiles were cooled at different mass-air ratios. 


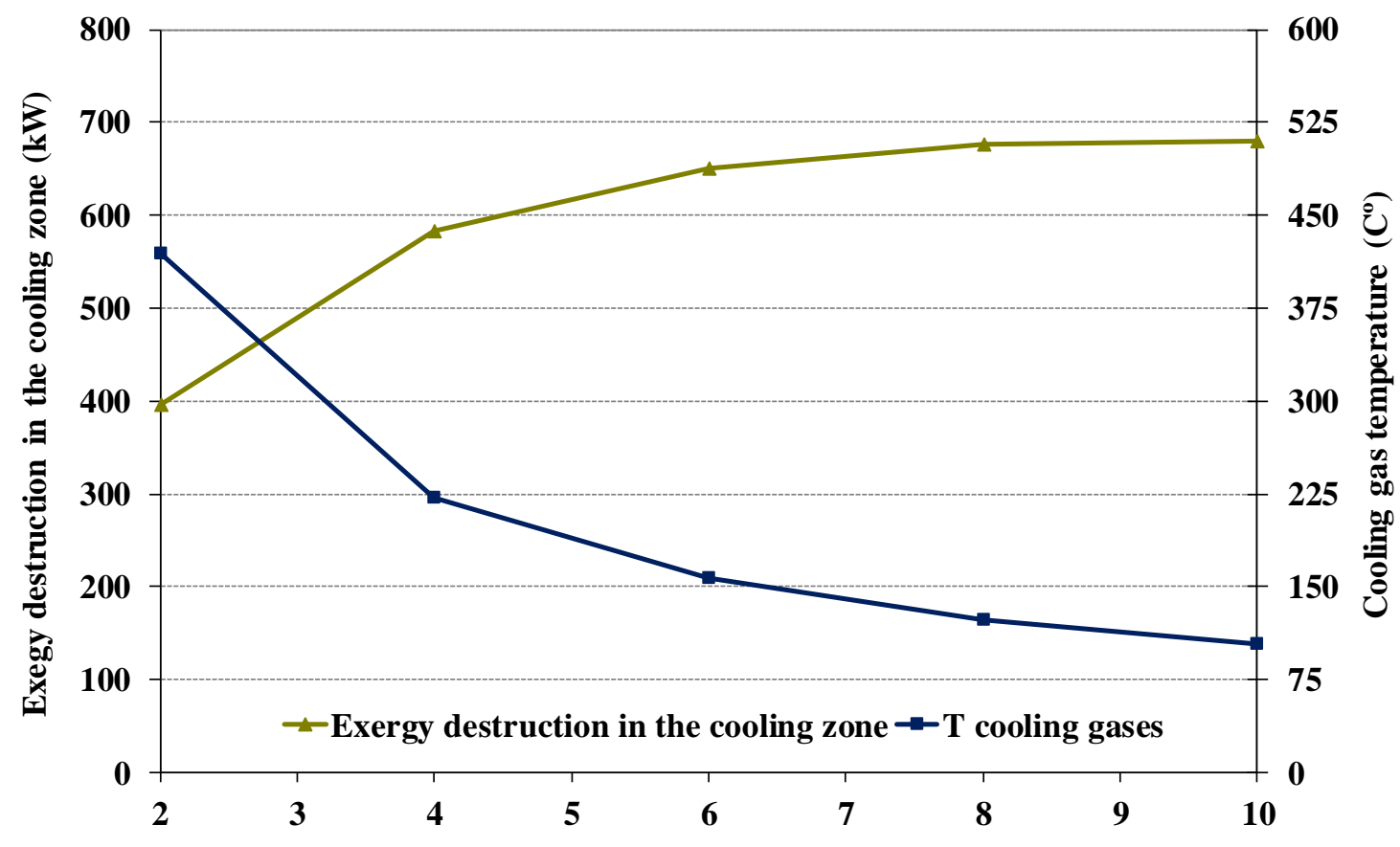

Cooling air-fired tile mass ratio (kg cooling air/kg fired tile)

Figure 11. Variation of exergy destruction with cooling air flow properties, keeping output stream enthalpy constant.

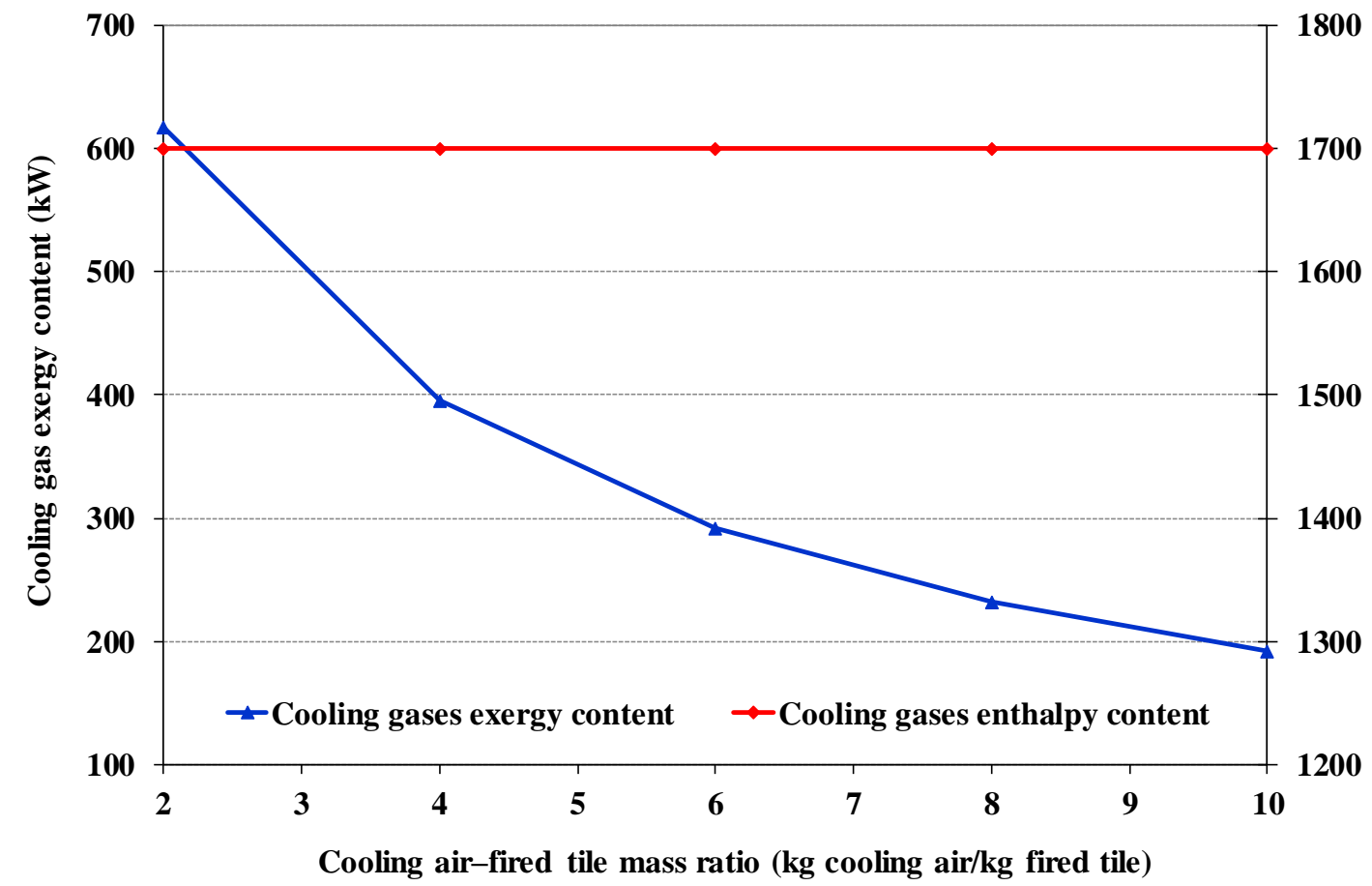

Figure 12. Variation of cooling gas exergy content with cooling air flow properties, keeping output stream enthalpy constant.

505 The results obtained indicate that exergy destruction during fired tile cooling could be reduced by introducing less air for fired tile cooling. This could be achieved by maximising air-fired tile contact, decreasing fired tile temperature more efficiently with less air. Exergy destruction in the 
cooling zone would therefore decrease significantly. In addition, cooling gas exergy content would increase significantly as the stream would have a lower air mass flow, albeit at a higher

510 temperature. This would increase energy quality and facilitate subsequent use, for example, in a heat recovery system. Obviously, from a practical point of view, such minimisation would depend on several factors (cooling area configuration, product characteristics, etc.). However, bearing these factors in mind, exergy destruction could be significantly reduced in most cases.

\section{Conclusions}

515 The studied ceramic tile firing kiln, which may be considered representative of single-deck roller kilns operating worldwide, exhibited very low energy performance, namely $15 \%$. Over $61 \%$ of the total energy input into the kiln was lost through the gas exhaust stacks. Such heat losses therefore need to be minimised and/or recovered.

The energy balance drawn up showed that the main factors to be addressed to improve kiln energy

520 performance were as follows:

(1) Implementation of heat recovery systems for the flue gases and cooling gases. In the studied kiln, the total thermal energy lost through the two stacks (flue and cooling exhaust gases) was about $2875 \mathrm{~kW}$, more than $61 \%$ of kiln energy consumption. This waste energy could be recovered to the same kiln as oxidising air or to other plant facilities by implementing energy saving actions.

(2) Optimisation of the oxidising air flow rate. The estimated excess air ratio in the studied kiln was 1.40 . This value is considered high, as $40 \%$ more than the air needed for stoichiometric combustion was being fed into the kiln. It is important to appropriately regulate the burners to prevent an excessive amount of oxidising air from entering the kiln, as this leads to increased energy losses through the flue gas exhaust stack.

(3) Improvement of kiln thermal insulation. About $20 \%$ of the energy input into the kiln was lost through kiln surfaces and uncontrolled heat losses. Kiln thermal insulation was therefore not good enough to prevent significant energy losses. The greatest losses occurred through the kiln vault, probably due to the greater deterioration of the refractory material located there, resulting 
535 from the rise by natural convection of the hot gases in the combustion chamber. The quality of kiln thermal insulation could be improved by reducing insulation thermal conductivity or increasing insulation thickness, in addition to improving the thermal sealing of kiln roller holders. In addition to energy efficiency, further analysis was performed by drawing up an exergy balance. This enabled identification and quantification of the main sources of irreversibilities in the kiln. Exergy analysis revealed a high rate of exergy loss in the kiln firing process, as only $10 \%$ of the total exergy input into the kiln was used in the targeted physico-chemical transformations of the porcelain tile composition. Total exergy destruction in the kiln because of irreversibilities was 83\%. The other exergy outputs (flue and cooling exhaust gases and kiln surface and wall losses) accounted for the remaining $17 \%$ exergy loss.

545 The main sources of irreversibility identified in the studied kiln were natural gas combustion (41\%), heat transfer in the fired tile cooling process (21\%), and heat transfer through kiln walls and vault (21\%). These factors are mainly influenced by the type of fuel, kiln technology, and kiln operating parameters. The following improvements, based on better management of the current facility without additional investments, are proposed for enhancing kiln energy efficiency:

550 (1) Optimisation of the oxidising air flow rate used for combustion. In these kilns, natural gas combustion is the main source of exergy destruction in the kiln. However, the exergy loss involved in combustion can be reduced by minimising the use of excess air and by preheating the reactants. Nevertheless, in most cases only a small part of the exergy destruction in the kiln combustion chamber can be avoided by these means. The studied kiln worked with an excess air 555 ratio of 1.40. By reducing this to 1.10 , the exergy loss associated with combustion would drop by $10 \%$ and kiln energy efficiency would increase.

(2) Optimisation of the cooling air ratio. Exergy destruction during fired tile cooling could be reduced by optimising the amount of air used to cool the fired tile. The studied kiln exhibited a ratio of $6.2 \mathrm{~kg}$ cooling air/ $\mathrm{kg}$ fired tile. Reducing this ratio to 4 , provided this is compatible with other system constraints, would reduce the exergy destruction associated with the cooling process by $11 \%$. Considering the same example, on reducing the ratio to $4 \mathrm{~kg}$ cooling air $/ \mathrm{kg}$ fired tile, the exergy contained in the cooling gases would increase by $71 \%$, as cooling gas temperature would 
rise; exergy quality would also increase, which would facilitate heat recovery by implementing energy saving actions.

565 In short, kiln efficiency could be optimised by implementing an optimum set of operating parameter values rather than simply optimal individual values. To select the optimum set of parameter values, avoidable and unavoidable exergy destruction and avoidable exergy losses in the process need to be identified. Kiln optimisation needs to focus on avoidable exergy destruction and avoidable exergy losses to achieve optimal kiln energy efficiency and ceramic tile quality.

\section{Acknowledgements}

This study was funded by the Valencian Institute of Business Competitiveness (IVACE) and the European Regional Development Fund (ERDF) through the project "Environmental challenges" (PROMECE project: IMAMCA/2016/1).

\section{References}

575 [1] Baraldi, L. World production and consumption of ceramic tiles. 2018. Ceramic World Review, 128/2018.

[2] AVEN, 2011a. Guía de ahorro energético en el sector de baldosas cerámicas de la Comunidad Valenciana. Plan de ahorro y eficiencia energética. Valencia. (In Spanish).

[3] AVEN, 2011b. Estudio energético sector de baldosas cerámicas de la Comunidad Valenciana. Valencia. (In Spanish).

[4] Barba, A.; Beltrán, V.; Feliu, C.; García, J.; Ginés, F.; Sánchez, E.; Sanz, V., 2002. Materias primas para la fabricación de soportes de baldosas cerámicas. Castellón: Instituto de Tecnología Cerámica. $2^{\mathrm{a}}$ edición. (In Spanish).

[5] IPTS. European Commission, 2007. Reference Document on Best Available Techniques in the Ceramic Manufacturing Industry. Available at http://eippcb.jrc.ec.europa.eu/reference/

[6] A. Mezquita, E. Monfort, S. Ferrer, D. Gabaldón-Estevan. 2017. How to reduce energy and water consumption in the preparation of raw materials for ceramic tile manufacturing: dry versus wet route. Journal of Cleaner Production, 168, pp. 1566-1570 
[7] Mezquita, A.; Monfort, E.; Zaera, V., 2009. Ceramic tiles manufacturing and emission 590 trading scheme: reduction of $\mathrm{CO}_{2}$ emissions, European benchmarking. Bol. Soc. Esp. Ceram. Vidr., 48(4), 211-222.

[8] Mezquita, A., Boix, J., Monfort, E., Mallol, G., 2014. Energy saving in ceramic tile kilns: Cooling gas heat recovery. Appl. Thermal Eng. 65 (4), 102-110.

[9] Monfort, E., Mezquita, A., Granel, R., Vaquer, E., Escrig, A., Miralles, A., Zaera, V., 2010. 595 Analysis of energy consumption and carbon dioxide emissions in ceramic tile manufacture. Bol. Soc. Esp. Ceram. Vidr., 49 (4), 303-310. (In Spanish).

[10] Directive 2003/87/EC of the European Parliament and of the Council of 13 October 2003 establishing a scheme for greenhouse gas emission allowance trading within the Community and amending Council Directive 96/61/EC.

600 [11] Directive 2009/29/EC of the European Parliament and of the Council of 23 April 2009 amending Directive 2003/87/EC so as to improve and extend the greenhouse gas emission allowance trading scheme of the Community.

[12] Celades, I., Moliner-Salvador, R., Ros-Dosda, T., Monfort, E., Zaera, V., 2012. Environmental development of the Spanish ceramic tile manufacturing sector over the period 605 1992-2007. Bol. Soc. Esp. Ceram. Vidr., 51 (2), 111-118.

[13] Cassani, F., 2010. Recovering energy-from kilns, dryers spray driers and mills. Cfi/Ber. DKG, 87(5), E35-E39.

[14] Peris, B., Navarro-Esbrí, J., Molés, F., Mota-Babiloni, A. 2015. Experimental study of an ORC (organic Rankine cycle) for low grade waste heat recovery in a ceramic industry. Energy, 85 , pp. 534-542.

[15] Maroncelli, M., Timellini, G., 1985. I consumi energetici nella produzione delle piastrelle ceramiche. Bologna: Centro Ceramico. (In Italian).

[16] Mezquita, A.; Monfort, E.; Vaquer, E.; Ferrer, S.; Arnal, M. A.; Toledo, J.; Cuesta, M. A., 2012. Energy optimization in ceramic tile manufacture by using thermal oil. World Congress on 615 Ceramic Tile Quality-Qualicer 2012 (available at www.qualicer.org). 
[17] Milani, M., Montorsi, L., Stefani, M., Saponelli, R., Lizzano, M., 2017. Numerical analysis of an entire ceramic kiln under actual operating conditions for the energy efficiency improvement. Journal of Environmental Management, 203, Part 3, 1026-1037.

[18] Delpech, B., Milani, M. Montorsi, L. Boscardin, D., Chauhan, A., Almahmoud, S., Axcell, 620 b., Jouhara, H. 2018. Energy efficiency enhancement and waste heat recovery in industrial processes by means of the heat pipe technology: Case of the ceramic industry. Energy, 158, p. $656-665$.

[19] Dincer, I., Rosen, M.A., 2007. Exergy, Energy, Environment and Sustainable Development. Elsevier, London.

625 [20] Sagastume, A., Vandecasteele, C. 2011. Exergy-based indicators to evaluate the possibilities to reduce fuel consumption in lime production. Energy, 36, pp. 2820-2827.

[21] Sagastume, A., Martínez, J.B.C, Vandecasteele, C. 2013. Energy and exergy assessments of a lime shaft kiln. Appl. Therm. Eng., 51, pp. 273-280.

[22] Shahin, H., Hassanpour, S., Saboonchi, A. 2016. Thermal energy analysis of a lime 630 production process: Rotary kiln, preheater and cooler. Energy Conversion and Management 114, $110-121$.

[23] Gürtürk, M.; Oztop, H.F., 2014. Energy and exergy analysis of a rotary kiln used for plaster production, Appl. Therm. Eng. 67, 554-565.

[24] Gürtürk, M., Oztop, H.F., Hepbasli, A. Energy and exergy assessments of a perlite 635 expansion furnace in a plaster plant. 2013. Energy Conversion and Management 75, 488-497.

[25] Gürtürk, M., Oztop, H.F., Hepbasli, A. Energy management and environmental aspects of a high capacity perlite furnace through exergetic analysis. 2014. Energy Conversion and Management 82, 188-201.

[26] Changxin Liu, Zhihui Xie, Fengrui Sun, Lingen Chen. 2017. Exergy analysis and optimization of cooking process. Energy, Volume 139, Pages 694-705.

[27] Wei Zhang, Juhua Zhang, Zhengliang Xue. 2017. Exergy analyses of the oxygen blast furnace with top gas recycling process. Energy, Volume 121, Pages 135-146. 
[28] Xiong Liu, Lingen Chen, Xiaoyong Qin, Fengrui Sun. 2015. Exergy loss minimization for a blast furnace with comparative analyses for energy flows and exergy flows. Energy, Volume 93, Part 1, Pages 10-19.

[29] Zhang, Y., Feng, J., Xu, J., Zhang, Y., Yang, J. 2011. Energy and exergy analyses of a mixed fuel-fired grate-kiln for iron ore pellet induration. Energy Conversion and Management 52, 2064-2071

[30] Çamdali, U., Tunç, M., Karakas, A. 2003. Second law analysis of thermodynamics in the 650 electric arc furnace at a steel producing company. Energy Conversion and Management 44, 961973.

[31] Takla, M., Kamfjord, N.E., Halvard Tveit, Kjelstrup, S. 2013. Energy and exergy analysis of the silicon production process. Energy, Volume 58, pp. 138-146.

[32] Domínguez, A., Valero, A, Valero, A. 2013. Exergy accounting applied to metallurgical 655 systems: The case of nickel processing. Energy, Volume 62, pp. 37-45.

[33] Ajith F.P., Arjun, C., Ramesh, A..2014. Energy and exergy analysis of a white cement kiln plant International Journal of Mechanical Engineering (IJME) Vol. 3, Issue 4.

[34] Amin Mirzakhani, M., Nassim Tahouni, Hassan Panjeshahi, M. 2017. Energy benchmarking of cement industry, based on Process Integration concepts. Energy, Volume 130, pp. 382-391.

[35] Atmaca, A., Yumrutas, R. 2014. Thermodynamic and exergoeconomic analysis of a cement plant: Part I - Methodology. Energy Conversion and Management 79, 790-798.

[36] Atmaca, A., Yumrutas, R. 2014. Thermodynamic and exergoeconomic analysis of a cement plant: Part II - Application. Energy Conversion and Management 79, 799-808.

[37] Çamdali, U., Erisen, A., Çelen, F. 2004. Energy and exergy analyses in a rotary burner with pre-calcinations in cement production. Energy Conversion and Management 45, 3017-3031. [38] Atmaca, A., M. Kanoglu, M. 2012. Reducing energy consumption of a raw mill in cement industry. Energy, 42 (1), pp. 261-269. 
[39] Kabir, G., Abubakar, A.I., El-Nafaty, U.A. 2010. Energy audit and conservation 670 opportunities for pyroprocessing unit of a typical dry process cement plant. Energy, 35, pp. 12371243.

[40] Koroneos, C., Roumbas, G., Moussiopoulos, N., 2005. Exergy analysis of cement production, International Journal of Exergy 2, p. 55-68.

[41] Madlool, N.A., Saidur, R., Rahim, N.A., Islam, M.R., Hossian, M.S., 2012. An exergy

675 analysis for cement industries: an overview, Renewable and Sustainable Energy Reviews 16, p. 921-932.

[42] Utlu, Z., Sogut, Z., Hepbasli, A., Oktay, Z., 2006. Energy and exergy analyses of a raw mill in cement production, Applied Thermal Engineering 26, p. 2479-2489.

[43] Ahmadi, G.R., Toghraie D. 2016. Energy and exergy analysis of Montazeri Steam Power Plant in Iran. Renew Sustain Energy Rev; 56:454-63.

[44] Ahmadi, G.R., Toghraie, D., Akbari, O.A. 2017. Efficiency Improvement of a Steam Power Plant Through Solar Repowering, Int. J. Exergy, Vol. 22, No. 2.

[45] Ahmadi, G.R., Toghraie, D., Akbari, O.A. 2017. Solar parallel feed water heating repowering of a steam power plant: A case study in Iran, Renewable and Sustainable Energy Reviews 77.

[46] Agrafiotis, C.; Tsoutsos, T., 2001. Energy saving technologies in the European ceramic sector: a systematic review. Appl. Thermal Eng. 21 (12), 131-1249.

[47] Bovea, M.D.; Díaz-Albo, E; Gallardo, A.; Colomer, F.J.; Serrano, J. Environmental performance of ceramic tiles: improvement proposals. Mater. Des., 31 (2010), pp. 35-41

690 [48] Eliche, D., Martinez, C., Martínez, M.L, Cotes, M.T, Pérez, L., Cruz, N. et al., 2011. The use of different forms of waste in the manufacture of ceramic Tricks. Appl. clay sci., 52, pp. 270276.

[49] Gabaldón-Estevan, D., Criado, E., Monfort, E., 2014. The Green Factor in European Manufacturing: a case study of the Spanish ceramic tile industry. J. Clean. Prod. 70, 242-250

695 [50] Nasseti, G. et al., 1998. Piastrelle ceramiche e energia: banca dati dei consumi energetici nell'industria delle piastrelle di ceramica. Sassuolo: Assopiastrelle. (In Italian). 
[51] Vogt, S.; Thomas, R., 2012. On the preparation of energy balances for brick and tilemaking plants (part 2). ZI Int., 64(10), 12-27.

[52] Abbakumov, V.G., 1975. Exergy analysis of tunnel kilns. Heat Engineering, pp. 555-565.

[53] Kandilli, C., Murat Ayna,, O., Sahin, M., 2015. Evaluation of the performance of a hydrogen enriched combustion system for ceramic sector. Appl. Therm. Eng., 40 (34), pp. 1119511206. doi:10.1016/j.ijhydene.2015.01.019

[54] Montasir A. Hader, Tariq T. Darabseh, Hussam A. AlOthman., 2011. Exergy Analysis of Ceramic Production in Jordan. Jordan Journal of Mechanical and Industrial Engineering. Volume 705 5, Number 6, pp. 483-488.

[55] Zafer, U., Hepbasli, A., Turan, M., 2011. Performance Analysis and Assessment of an Industrial Dryer in Ceramic Production, Drying Technology: An International Journal, 29:15, $1792-1813$.

[56] Zafer, U, Hepbasli, A., 2014. Exergoeconomic analysis of energy utilization of drying 710 process in a ceramic production Appl. Therm. Eng.,70, p.748-762.

[57] Ferrer, S., Mezquita, A., Gomez-Tena, M., Machi, C., Monfort, E. 2015. Estimation of the heat of reaction in traditional ceramic compositions. Appl. Clay Science, 108, 28-39. doi:10.1016/j.clay.2015.02.019

[58] Mallol, G., Monfort, E., Busani, G., Lezaun, J., 2001. Depuración de los gases de combustión en la Industria Cerámica: guía técnica. (In Spanish).

[59] IPCC, Intergovernmental Panel on Climate Change, 2006. Guidelines for National $\begin{array}{lllll}\text { Greenhouse Gas Inventories. Volume 2: Energy. http://www.ipcc- } & \end{array}$ nggip.iges.or.jp/public/2006gl/index.html

[60] Binnewies, M. and Milke, E., 1999. Thermochemical Data of Elements and Compounds. Wiley-VCH.

[61] Chermak, J.A., Rimstidt, J.D., 1989. Estimating the thermodynamic properties $\left(\Delta \mathrm{G}_{\mathrm{f}}^{0}\right.$ and $\left.\Delta \mathrm{H}_{\mathrm{f}}{ }^{0}\right)$ of silicate minerals at $298 \mathrm{~K}$ from the sum of polyhedral contributions. Am. Mineral. 74, 1023-1031. 
[62] Robie, R. A., Hemmingway, B. S., \& Fisher, J. R., 1978. Thermodynamic Properties of 725 Minerals and Related Substances at 298.15 K and 1 Bar (105 Pascals) Pressure and at Higher Temperatures U.S. Geological survey bulletin 1452.

[63] Szargut, J., Morris, D.R., 1986. Standard chemical exergy of some elements and compounds on the planet earth. Energy, 11 (8), pp. 733-755.

[64] Szargut, J., 2005. Exergy Method. Technical and Ecological Applications, WIT. Pess, 730 Southampton, UK.

[65] Çengel Y.A. and Boles M.A., 2006. Thermodynamics: An Engineering Approach, 5 th ed. McGraw-Hill. New York.

[66] Davis, P.; Garapin, F. Processus de calcul d'un bilan thermique. 1978. L'industrie céramique, No 716, 4/78, p. 257-269. (In French)

735 [67] Michael S. Crowley and Jack S. Young. 1988. Thermal conductivity of monolithic refractories. American Ceramic Society Bulletin, 67 [7] 1196-1200.

[68] Perry, Robert H., Don W. Green, and James O. Maloney. 2001. Perry's Chemical Engineers' Handbook. New York: McGraw-Hill.

[69] Moran, M. J. and Howard N. Shapiro, 2006. Fundamentals of engineering thermodynamics. John Wiley \& Sons.

[70] Valero, A., 2008. Estudio de la evolución exergética del capital mineral de la tierra. Doctoral thesis (in Spanish). Dpto. de Ing. Mecánica. Universidad de Zaragoza. Spain. (available at https://www.educacion.gob.es/teseo)

[71] Ferrer, S., 2016. Energy and exergy analysis of the firing process of ceramic 745 compositions. Doctoral thesis (in Spanish). Universitat Jaume I. Castellón. Spain. (available at https://www.educacion.gob.es/teseo)

[72] Lozano M.A. y Valero, A., 1986. Determinación de la exergía para sustancias de interés industrial. Ingeniería Química, Número 204, p. 119-128. (in Spanish). 
[73] Ros-Dosdá, T., Fullana, P., Mezquita, A., Masoni, P., Monfort, E. 2018. How can the 750 European ceramic tile industry meet the EU's low-carbon targets? A life cycle perspective. Journal of Cleaner Production, 199, pp. 554-564. 